\title{
Electrooxidation of methanol and ethanol on carbon electrodeposited Ni-MgO nanocomposite
}

\author{
H. B. Hassan a,*, Z. Abdel Hamid b,\#, Rabab M. El-Sherif a \\ a Chemistry Department, Faculty of Science, Cairo University, Giza, Egypt \\ ${ }^{\mathrm{b}}$ Central Metallurgical Research and Development Institute, Cairo, Egypt
}

\section{A R T I C L E I N F O}

Article history:

Received 11 October 2015

Accepted 22 December 2015

Published 5 April 2016

\section{Keywords:}

Nickel-modified manganese oxide

Electrooxidation

Methanol

Ethanol

Electrochemical impedance

spectroscopy

Cyclic voltammetry

\begin{abstract}
A B S T R A C T
$\mathrm{Ni}-\mathrm{MgO}$ nano-composites were prepared on carbon anodes by electrodeposition from a nickel Watts bath in the presence of fine $\mathrm{MgO}$ reinforcement particles. Their performance as electrocatalysts for the oxidation of methanol and ethanol in alkaline medium was investigated and compared with that of carbon coated pure $\mathrm{Ni}(\mathrm{Ni} / \mathrm{C})$. The chemical composition, phase structure, and surface morphology of the deposited nano-composites were studied by energy dispersive X-ray spectroscopy, X-ray diffractometry, and scanning electron microscopy, respectively. Different electrochemical techniques were used to estimate the catalytic activity of the prepared electrocatalyst anodes, including cyclic voltammetry (CV), chronoamperometry, and electrochemical impedance spectroscopy (EIS). The Ni/C electrocatalyst alone exhibited remarkably low catalytic activity and poor stability toward the electrooxidation process. The inclusion of MgO significantly promoted the catalytic activity of the $\mathrm{Ni}$ catalyst for the alcohol electrooxidation and enhanced its poisoning resistance. The EIS results confirmed those of CV and revealed a lower charge transfer resistance and enhanced roughness for the $\mathrm{Ni}-\mathrm{MgO} / \mathrm{C}$ nano-composite electrodes compared with those of $\mathrm{Ni} / \mathrm{C}$.
\end{abstract}

(C) 2016, Dalian Institute of Chemical Physics, Chinese Academy of Sciences. Published by Elsevier B.V. All rights reserved.

\section{Introduction}

Research on direct alcohol fuel cells (DAFCs) has gained momentum because they are considered to be promising power sources for many applications such as portable electronic devices and electric vehicles [1,2]. However, the commercialization of fuel cells is still suffering many problems, particularly for those using acid media, owing to kinetic restriction of the methanol oxidation reaction (MOR) and the high catalyst cost that prevents the use of Pt at a commercial level [3].

However, the efficiency of the methanol or ethanol electrooxidation reaction in alkaline electrolyte is clearly better than that in acidic electrolyte, and there is a wider choice of catalysts that are operable in alkaline electrolytes [4,5]. Taking these limitations into consideration, it has become necessary to move toward optimization of alternative electroactive catalysts for the oxidation process. The limited choice of efficient, highly active, available, and cheap anode catalysts for DAFCs is still a great challenge for energy conversion systems [6]. Considerable efforts have been devoted to the fabrication of high performance Ni-based catalysts for the electrooxidation of methanol and ethanol in alkaline media [7-13]. Ni is a relatively low cost material and is produced in large amounts; moreover, it displays potential catalytic properties in a wide number of processes such as energy conversion in alkaline fuel cells [14,15]. The electrocatalytic properties of $\mathrm{Ni}$ in alkaline media depend on the formation of nickel hydroxide $\left(\mathrm{Ni}(\mathrm{OH})_{2}\right)$ and oxyhydroxide $(\mathrm{NiOOH})$ species under anodic polarization [16].

\footnotetext{
*Corresponding author. Tel: +20-1003871963; E-mail: hanaa20055@hotmail.com

\# Corresponding author. E-mail: zamiabdelhamid@hotmail.com

DOI: 10.1016/S1872-2067(15)61034-8 | http://www.sciencedirect.com/science/journal/18722067 | Chin. J. Catal., Vol. 37, No. 4, April 2016
} 
Recently, metal oxide composites have attracted significant attention as electrocatalysts owing to their low cost, easy preparation methods, and excellent catalytic activity [17]. $\mathrm{Ni}$-metal oxide composite films have been reported to be much superior to pure $\mathrm{Ni}$ films in respect to the electrocatalysis of methanol and ethanol oxidation $[6,7,18]$. Composite electroplating is one of the various techniques that have been used to prepare efficient $\mathrm{Ni}$ composites. This method involves the co-deposition of fine particles such as $\mathrm{ZnO}, \mathrm{TiO}_{2}, \mathrm{Al}_{2} \mathrm{O}_{3}$, or $\mathrm{Cr}_{2} \mathrm{O}_{3}$ into a plated layer under the effect of an electric field $[6,7,19-23]$. The rate of fine particle inclusion depends on the size, shape, and charge of the particles. It also depends on the plating conditions, such as current density, temperature, $\mathrm{pH}$, and time. In our previous work [6,23], we have successfully demonstrated the possibility of fabricating $\mathrm{Ni}$-metal oxide nanoparticles on carbon electrodes using electrodeposition or electroless techniques.

The enhancement effect of the incorporation of reinforcement particles such as metal oxides on the catalytic activities of metal catalysts has been demonstrated in the literature. It has been found that incorporating oxide particles results in a low overvoltage for alcohol oxidation, and they act as effective anode materials [23]. $\mathrm{TiO}_{2}$ or $\mathrm{Cr}_{2} \mathrm{O}_{3}$ deposited with $\mathrm{Ni}$ as a nanocomposite improves the electrocatalytic activity and stability of the $\mathrm{Ni}$ in electrooxidation processes $[6,7,23]$. The use of $\mathrm{CeO}_{2}$, $\mathrm{Co}_{3} \mathrm{O}_{4}$, or $\mathrm{Mn}_{3} \mathrm{O}_{4}$ can remarkably enhance the catalytic activity and reduce the usage of precious metal catalysts [24]. Adding $\mathrm{Co}_{3} \mathrm{O}_{4}$ nanoparticles to multiwalled carbon nanotubes (MWCNTs) enhances the surface area of the modified electrode and the electron transfer rate for hydrogen peroxide detection [25]. $\mathrm{Ni}-\mathrm{V}_{2} \mathrm{O}_{5}$ exhibits high electrocatalytic activity toward dopamine (DA) oxidation owing to the promotion of the electroactive $\mathrm{V}^{5+} / \mathrm{V}^{4+}$ redox reaction by $\mathrm{Ni}^{2+}$ [26]. Pt-CoO electrode has shown electrocatalytic activity toward the mediated electrooxidation of ascorbic acid, glucose, and methanol [27]. The addition of $\mathrm{NiO}$ to $\mathrm{Pt} / \mathrm{C}$ or $\mathrm{Pd} / \mathrm{C}$ improved the catalytic activity and poisoning resistance of the electrodes toward methanol electrooxidation [28]. Additionally, Ni-modified MgO is significantly active for the electrooxidation of methanol [29]. Finally, MgO increases the anti-poisoning ability of the catalyst and improves the kinetic processes [30].

Several different strategies have been attempted in the literature to improve the catalytic activities of Ni-based catalysts, including the use of $\mathrm{Ni}$-metal oxide composites. However, the role of such metal oxides in enhancing the catalytic activities of Ni catalysts toward the electrooxidation of methanol or ethanol has not studied yet and needs further investigation. The purpose of the present work was to synthesize and study the performance of $\mathrm{Ni}-\mathrm{MgO}$ composites supported on carbon as potential electrocatalysts for fuel cells. $\mathrm{Ni}-\mathrm{MgO}$ composites were prepared using a facile electrodeposition route. The role of $\mathrm{MgO}$ in enhancing the catalytic activity, anti-poisoning ability, and stability of the Ni catalyst during the electrocatalytic oxidation of methanol and ethanol in alkaline environment was elucidated through surface investigation and electrochemical techniques.

\section{Experimental}

\subsection{Pretreatment and preparation of the electrode}

Carbon substrates were mechanically polished using emery papers of different grades up to 1000, and subsequently degreased with acetone, rinsed with triply distilled water, and dried with soft tissue paper. The apparent surface area of the substrates was calculated from the geometric area and the current density referred to below. A Nickel Watts bath was used to deposit $\mathrm{Ni}$ or $\mathrm{Ni}-\mathrm{MgO}$ composite film on the carbon substrates using a galvanostatic technique. The composition of the deposition bath and the operating conditions are given in Table 1. Pure Ni metal and carbon electrodes were used as the anode and cathode, respectively. Prior to the co-deposition, MgO particles having an average particle size of $\sim 8 \mu \mathrm{m}$ were stirred in the plating solution for about $2 \mathrm{~h}$ using a magnetic stirrer at $150 \mathrm{r} / \mathrm{min}$ to obtain a uniform suspension and prevent agglomeration of the Mg0. During the co-deposition process, the bath also was stirred with a magnetic stirrer (150 $\mathrm{r} / \mathrm{min}$ ) to keep the particles dispersed and prevent their sedimentation in the electrolyte. Various composite electrodes were prepared at different deposition current densities. After the preparation of the modified carbon electrodes, no further pretreatment of the electrode was carried out to avoid any changes to the electrode surface.

\subsection{Electrochemical measurements}

A conventional three-electrode glass cell was used for electrochemical studies. The reference electrode was $\mathrm{Hg} / \mathrm{HgO} / 1.0$ $\mathrm{mol} / \mathrm{L} \mathrm{NaOH}$ (MMO) ( $E_{0}=0.140 \mathrm{~V}$ vs NHE), and a Pt sheet was used as a counter electrode. Measurements were carried out at room temperature $\left(30 \pm 1{ }^{\circ} \mathrm{C}\right)$ in $1.0 \mathrm{~mol} / \mathrm{L} \mathrm{NaOH}$ solution. Ethanol and methanol were used as received without further purification. All the reagents used in this work were Sigma-Aldrich products of analytical grade and were used without further purifications. Triply distilled water was used throughout for the preparation of solutions.

The electrochemical measurements were performed using cyclic voltammetry (CV) and chronoamperometry techniques using an IviumStat instrument (Ivium Technologies, Eindhoven, the Netherlands). The IviumSoft software was used to control the instrument through a personal computer (PC). The PC was used to specify the parameters of the measurement, display the measured curves, and calculate the results of the measurements. Electrochemical impedance spectroscopy (EIS)

\section{Table 1}

Chemical composition of $\mathrm{Ni}$ electroplating electrolyte and the operating conditions for electrodeposition of $\mathrm{Ni}$ composite coatings on carbon electrode.

\begin{tabular}{lcc}
\hline Composition & Concentration (g/L) & Operating conditions \\
\hline $\mathrm{NiSO}_{4}$ & 240 & pH 5 \\
$\mathrm{NiCl}_{2}$ & 45 & Deposition temperature: $55^{\circ} \mathrm{C}$ \\
$\mathrm{H}_{3} \mathrm{BO}_{3}$ & 30 & Deposition time: 30 min \\
$\mathrm{MgO}$ & 10 & Deposition current density: \\
& & $10-80 \mathrm{~mA} / \mathrm{cm}^{2}$ \\
\hline
\end{tabular}


was carried out using a Zahner Elektrik IM6 electrochemical workstation. The peak to peak amplitude of the superimposed AC-signal was $10 \mathrm{mV}$. The impedance, $Z$, and the phase shift of the electrochemical system were directly measured in the frequency range from 0.1 to $10^{4} \mathrm{~Hz}$. To ensure reproducibility, each experiment was carried out at least three times. The details of the experimental procedures and preparation have been described elsewhere [31].

Before the deposition process, the zeta potential of the $\mathrm{MgO}$ particles was measured using a laser zeta meter (Zetasizer 2000, Malvern Instruments, UK). A powdered sample of the $\mathrm{MgO}$ (about $0.02 \mathrm{~g}$ ) was placed into $50 \mathrm{~mL}$ of Nickel Watts electroplating solution at $\mathrm{pH}=5$ and the sample was stirred for $60 \mathrm{~min}$, after which the zeta potential was measured.

\subsection{Surface analysis}

A JEOL JSM-5410 scanning electron microscope (SEM) equipped with an energy dispersive X-ray system (EDX) was used to investigate the surface morphology and elemental composition of the deposits, respectively. The phase structure and the particle size of the deposited films were characterized by X-ray diffraction (XRD) analysis using a PANalytical X pert PRO with $\mathrm{Cu} K_{\alpha} 1$ radiation of $0.15046 \mathrm{~nm}$ wavelength and operated at $45 \mathrm{kV}$ and $40 \mathrm{~mA}$. The scanning step size, rate, and range were $0.02^{\circ}, 0.05^{\circ} / \mathrm{s}$, and $10^{\circ}-100^{\circ}$, respectively.

\section{Results and discussion}

\subsection{Electrodeposition and surface characterization}

Different $\mathrm{Ni}-\mathrm{MgO} / \mathrm{C}$ electrodes were prepared by electrodeposition at deposition current densities of $10,20,40$, and 80 $\mathrm{mA} / \mathrm{cm}^{2}$ in the presence of a fixed amount of $\mathrm{MgO}$ particles $(10$ $\mathrm{g} / \mathrm{L}$ ) in the plating electrolyte. All other deposition parameters were kept constant. For comparison, a Ni/C electrode was also prepared under the same conditions, but without the MgO particles in the plating electrolyte. The effect of the current density of the deposition on the amount of MgO incorporated into the composite layer was investigated, and the results are presented in Figs. 1 and 2. Fig. 1 shows the results of the EDX analysis of $\mathrm{Ni} / \mathrm{C}$ and $\mathrm{Ni}-\mathrm{MgO} / \mathrm{C}$ electrodes prepared at $10 \mathrm{~mA} / \mathrm{cm}^{2}$ in the absence and presence of $\mathrm{MgO}$ particles in the plating solution. Characteristic peaks for $\mathrm{Ni}, \mathrm{O}$, and $\mathrm{Mg}$ were observed in the EDX spectrum of the $\mathrm{Ni}-\mathrm{MgO} / \mathrm{C}$ electrode, but only peaks for $\mathrm{Ni}$ were observed for the $\mathrm{Ni} / \mathrm{C}$ electrode. The wt\% of $\mathrm{MgO}$ in the deposited layer was found to increase with the current density of the deposition process (Fig. 2), up to $12 \mathrm{wt} \%$ at a deposition current density of $40 \mathrm{~mA} / \mathrm{cm}^{2}$. Increasing the deposition current density accelerated the electrophoretic velocity of the $\mathrm{MgO}$ particles and increased the Coulombic force between $\mathrm{Ni}^{2+}$ adsorbed on MgO particles and the cathode surface, resulting in an increased $\mathrm{MgO}$ content in the $\mathrm{Ni}$ deposit [32]. However, at a relatively high deposition current density of $80 \mathrm{~mA} / \mathrm{cm}^{2}$, the amount of $\mathrm{MgO}$ particles in the deposit slightly decreased and the efficiency of the deposition process declined. This may have been caused by vigorous hydrogen evolution competing with
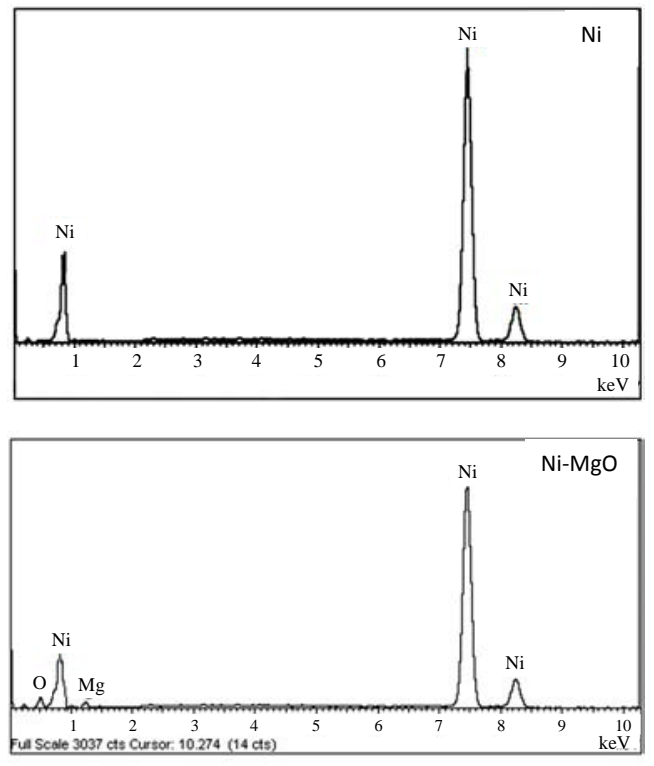

Fig. 1. EDX analysis results of $\mathrm{Ni} / \mathrm{C}$ and $\mathrm{Ni}-\mathrm{MgO} / \mathrm{C}$ electrode prepared from Ni Watts bath in the absence and presence of $10 \mathrm{~g} / \mathrm{L} \mathrm{MgO} \mathrm{parti-}$ cles.

the deposition process [33]. Moreover, at a relatively high current density, the rate of charge transfer is relatively high, so the reduction process is controlled by mass transfer. Accordingly, the deposition rate of the $\mathrm{Ni}-\mathrm{MgO}$ composite gradually decreased owing to the depletion of the metal cations in the vicinity of the cathode surface. The co-deposition process can be explained based on the adsorption of metal ions onto fine particles [34,35]. Solid particles in an electrolyte are electrolytically charged by the adsorption of ions on their surfaces. The sign and magnitude of the electrolytic charge is known as the zeta potential and depends on the $\mathrm{pH}$ of the solution [36]. The mechanism of the electrodeposition of the solid particles in this work can be suggested as the adsorption of positively charged $\mathrm{Ni}^{2+}$ in the electrolyte onto the negatively charged solid particles, which then migrated to the cathode. At the cathode, the metal ions were reduced to $\mathrm{Ni}$ to form coatings, with the entrapped solid particles occupying a place in the metal matrix. In this work, the zeta potential of the MgO particles had a negative value of $-16.8 \mathrm{mV}$ at the operating $\mathrm{pH}$ of 5 . The negative zeta potential prevented the $\mathrm{MgO}$ particles from agglomerating in

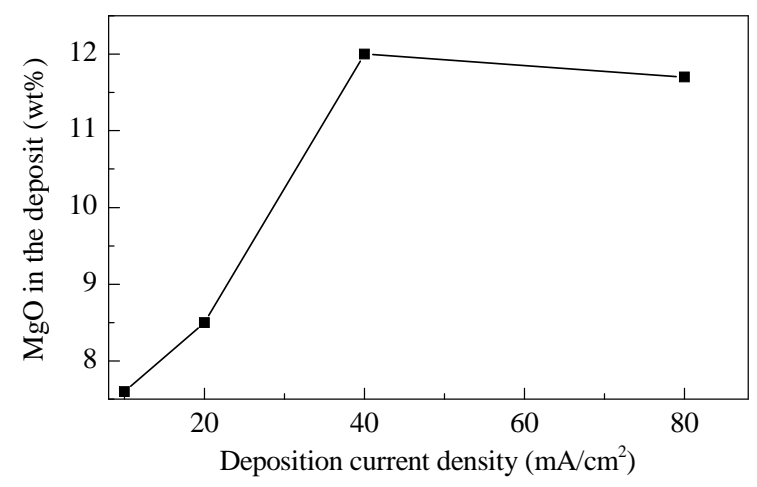

Fig. 2. Dependence of MgO content in the deposit on the deposition current density in the presence of $10 \mathrm{~g} / \mathrm{L} \mathrm{MgO}$ particles. 
the electrolyte solution during the deposition process and aided the adsorption of $\mathrm{Ni}^{2+}$ ions on the $\mathrm{MgO}$ surface. Under the effect of the mechanical stirring, MgO particles with adsorbed $\mathrm{Ni}^{2+}$ were transported to the cathode surface, where the $\mathrm{Ni}^{2+}$ discharged into $\mathrm{Ni}$ and the $\mathrm{MgO}$ was trapped in the deposited metal. Furthermore, the rate of metal discharge as well as the incorporation of the fine particles into the metal matrix depends on the current density [32]. In this work, the rate of the co-deposition process was found to generally increase with the current density, and the optimum deposition current density was $40 \mathrm{~mA} / \mathrm{cm}^{2}$.

The surface morphology of the $\mathrm{Ni} / \mathrm{C}$ and $\mathrm{Ni}-\mathrm{MgO} / \mathrm{C}$ samples was investigated by SEM (Fig. 3). It shows typical SEM micrographs of the electrodeposited Ni/C electrodes (Fig. 3(a), (c), and (e)), which revealed a regular pyramidal structure of $\mathrm{Ni}$ crystallites for all samples. Notably, the particle size of the $\mathrm{Ni}$ decreased as the deposition current density was increased. In contrast, the co-deposition of MgO particles in the metal deposit induced changes in the structure of the nickel matrix. The SEM images of the $\mathrm{Ni}-\mathrm{MgO} / \mathrm{C}$ composite electrodes (Fig. 3(b), (d), and (f)) indicated that the morphology of the Ni particles changed to an oval rod-like structure homogenously distributed on the electrode surface. Notably, a good dispersion of $\mathrm{Ni}$ particles on the carbon substrate was observed for the composite electrodes. The presence of MgO particles in the deposit was found to reduce the size of the Ni grains, owing to the distribution of $\mathrm{MgO}$ particles on the boundaries of Ni grains, which limited the growth of the Ni grains during the deposition process and resulted in refinement of the surface. A decrease in the grain size of the deposits was achieved by increasing the deposition current density. This behavior is attributed to the faster transport of metallic ions to the cathode by diffusion than by

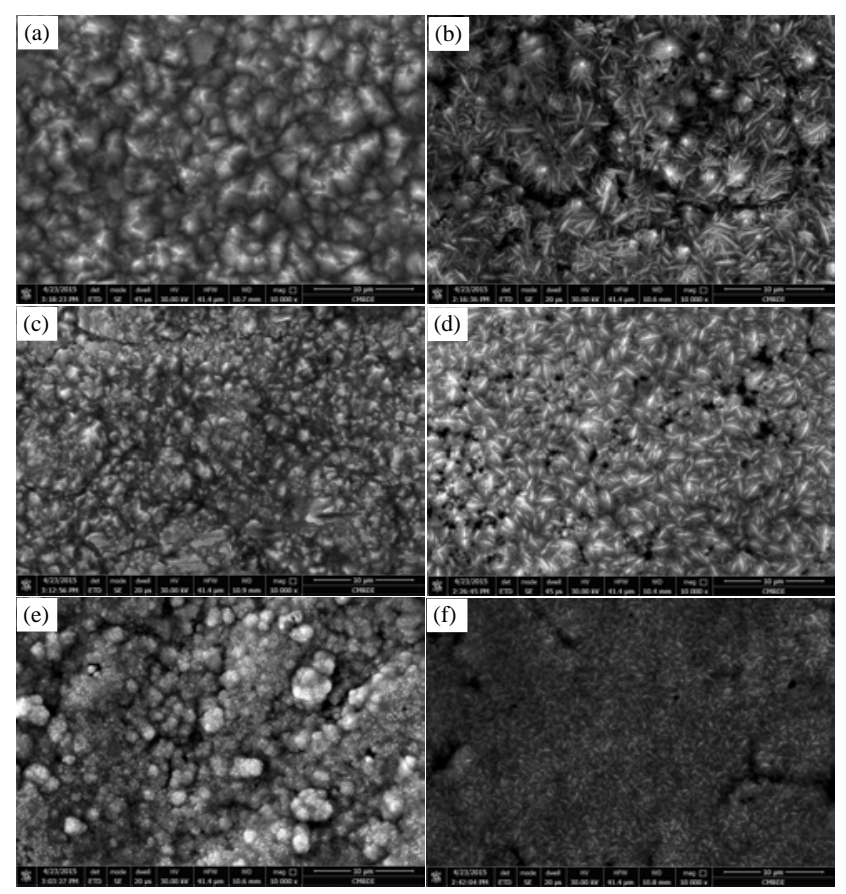

Fig. 3. SEM images of $\mathrm{Ni} / \mathrm{C}(\mathrm{a}, \mathrm{c}, \mathrm{e})$ and $\mathrm{Ni}-\mathrm{MgO} / \mathrm{C}(\mathrm{b}, \mathrm{d}, \mathrm{f})$ electrodes prepared at different deposition current densities of $20(a, b), 40(c, d)$, and $80 \mathrm{~mA} / \mathrm{cm}^{2}(\mathrm{e}, \mathrm{f})$ from Ni Watts bath.

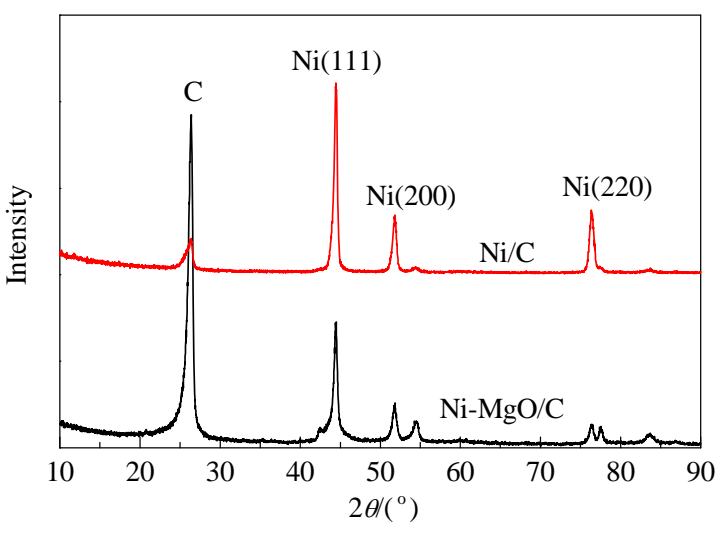

Fig. 4. XRD patterns of $\mathrm{Ni} / \mathrm{C}$ and $\mathrm{Ni}-\mathrm{MgO} / \mathrm{C}$ composite electrodes prepared from Ni Watts bath in absence and presence of $10 \mathrm{~g} / \mathrm{L} \mathrm{MgO}$ particles.

mechanical agitation [37]. In general, a high deposition current density promotes grain refinement [38-40]. However, a few cracks were observed in the micrograph of the $\mathrm{Ni}-\mathrm{MgO} / \mathrm{C}$ composite prepared at $80 \mathrm{~mA} / \mathrm{cm}^{2}$; this could have been caused by the hydrogen evolution reaction at such a high deposition current density. At the same time, the increase in the deposition current density resulted in a higher overpotential that increased the deposition rate [41].

Phase analysis of the pure $\mathrm{Ni}$ and $\mathrm{Ni}-\mathrm{MgO}$ composite coatings was performed by XRD, as shown in Fig. 4. The pattern of the pure Ni layer showed three diffraction peaks, at $44.5^{\circ}$, $51.8^{\circ}$, and $76.3^{\circ}$, which corresponded to the (111), (200), and (220) planes of crystalline Ni metal, respectively, according to the standard crystallographic pattern of Ni (JCPDS 40-0850). The same diffraction peaks were observed for $\mathrm{Ni}-\mathrm{MgO}$, but with lower intensities. The Ni(111), (200), and (220) peaks were used to calculate the particle size of the $\mathrm{Ni}$ deposits according to Scherrer's equation [42]. The average Ni particle size decreased with increasing deposition current density, as shown in Table 2. Notably, the particle size of the Ni in the composite coating was smaller than that of the pure Ni coating at all studied deposition current densities. The results show that the addition of MgO favors the forming of small Ni grains.

The fabricated composites were expected to be advantageous for use as electrocatalysts for electrooxidation processes owing to their smaller Ni grain size, which may result in large surface area. Generally, a better catalytic efficiency is achieved as the size of the catalyst particles is reduced. So, the $\mathrm{Ni}-\mathrm{MgO}$ composite was expected to be a more active electrocatalyst than pure $\mathrm{Ni} / \mathrm{C}$.

Table 2

The particle size of $\mathrm{Ni} / \mathrm{C}$ and $\mathrm{Ni}-\mathrm{MgO} / \mathrm{C}$ composite coatings prepared at different deposition current densities in the absence and presence of 10 $\mathrm{g} / \mathrm{L} \mathrm{MgO}$ in the plating solution on carbon electrodes.

\begin{tabular}{lcc}
\hline $\begin{array}{l}\text { Deposition current density } \\
\left(\mathrm{mA} / \mathrm{cm}^{2}\right)\end{array}$ & \multicolumn{2}{c}{ Particle size $(\mathrm{nm})$} \\
\cline { 2 - 3 } & $\mathrm{Ni} / \mathrm{C}$ & $\mathrm{Ni}-\mathrm{MgO} / \mathrm{C}$ \\
\hline 10 & 45.0 & 36.0 \\
20 & 30.7 & 20.3 \\
40 & 28.6 & 18.0 \\
80 & 17.0 & 16.8 \\
\hline
\end{tabular}




\subsection{Electrocatalytic activity of synthesized electrodes}

The electrocatalytic performance of the fabricated $\mathrm{Ni}-\mathrm{MgO} / \mathrm{C}$ electrodes prepared at different deposition current densities was investigated by cyclic voltammetry in $1.0 \mathrm{~mol} / \mathrm{L}$ $\mathrm{NaOH}$ solution in the absence and presence of $1.0 \mathrm{~mol} / \mathrm{L}$ methanol and in $1.0 \mathrm{~mol} / \mathrm{L}$ ethanol, and compared with the catalytic activity of $\mathrm{Ni} / \mathrm{C}$ electrodes prepared under the same experimental conditions. Fig. 5(a) shows the cyclic voltammograms recorded for the $\mathrm{Ni} / \mathrm{C}$ electrodes in $1.0 \mathrm{~mol} / \mathrm{L} \mathrm{NaOH}$ at $50 \mathrm{mV} / \mathrm{s}$ in the potential range of -0.5 to $+1.2 \mathrm{~V}$ (MMO). A pair of well defined redox peaks was observed at about $+0.5 \mathrm{~V}$ (MMO) (anodic peak) and $+0.35 \mathrm{~V}$ (MMO) (cathodic peak), which was attributed to the formation of the $\mathrm{Ni}(\mathrm{OH})_{2} / \mathrm{NiOOH}$ pair $[16,43,44]$. Interestingly, the anodic peak was slightly shifted toward a more positive potential and the cathodic peak was slightly shifted toward a less positive potential as the deposition current density was increased. Also, the current density of these redox peaks increased with the deposition current density of electrode up to $40 \mathrm{~mA} / \mathrm{cm}^{2}$, and then slightly de-
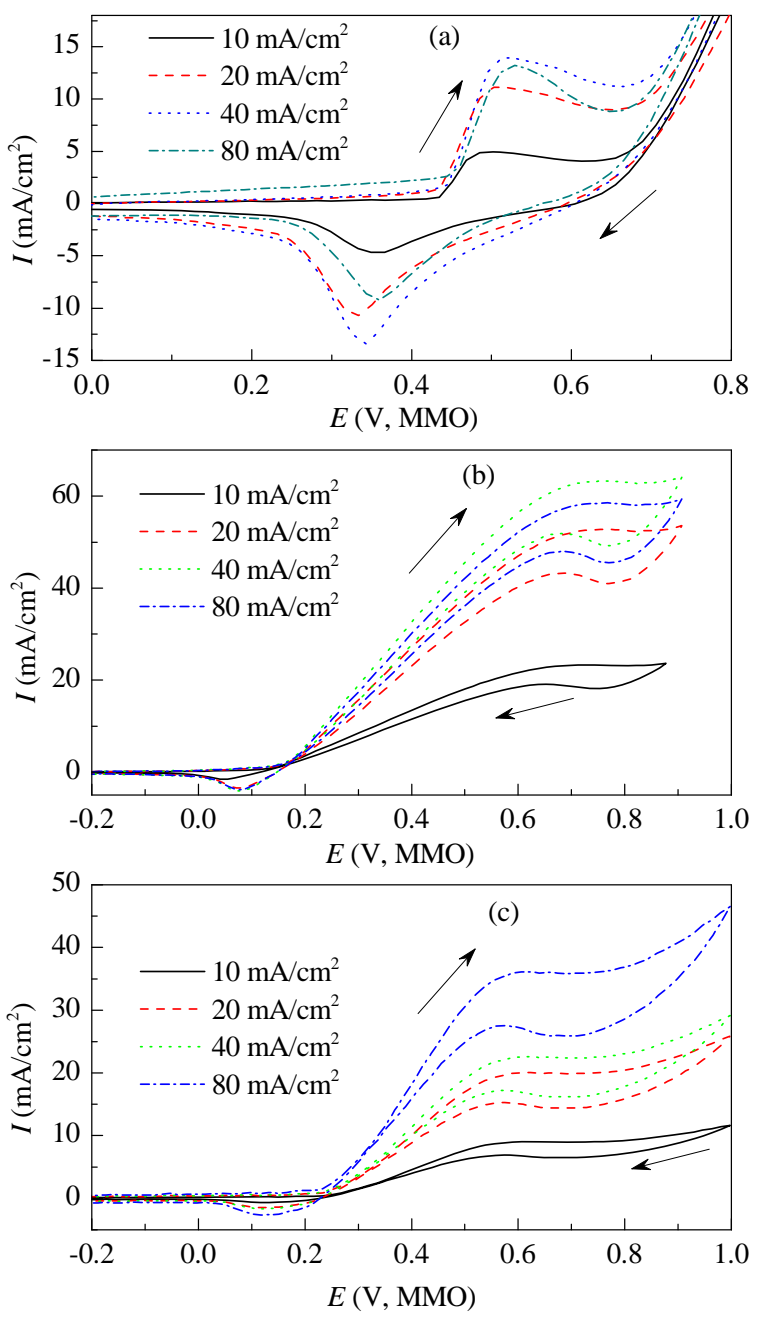

Fig. 5. Cyclic voltammograms of $\mathrm{Ni} / \mathrm{C}$ electrodes prepared at different deposition current densities in $1.0 \mathrm{~mol} / \mathrm{L} \mathrm{NaOH} \mathrm{(a),} 1.0 \mathrm{~mol} / \mathrm{L} \mathrm{NaOH}+$

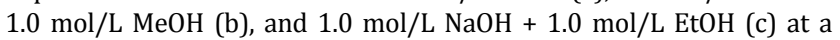
scan rate of $50 \mathrm{mV} / \mathrm{s}$. clined at $80 \mathrm{~mA} / \mathrm{cm}^{2}$. In the anodic part, the oxidation of nickel hydroxide generated $\mathrm{NiOOH}$, which is the most important species required for alcohol oxidation [45].

Upon adding $1.0 \mathrm{~mol} / \mathrm{L}$ methanol to the blank electrolyte, the onset potential for methanol oxidation was found to be consistent with the potential corresponding to $\mathrm{Ni}$ (III) species formation. The current density of the methanol oxidation peak increased with the deposition current density for all of the prepared electrodes, reaching a maximum current density value of $65 \mathrm{~mA} / \mathrm{cm}^{2}$ at $+0.74 \mathrm{~V}$ (MMO) for the electrodes prepared at $40 \mathrm{~mA} / \mathrm{cm}^{2}$ (Fig. 5(b)). The current density of the oxidation peak observed in the case $1.0 \mathrm{~mol} / \mathrm{L}$ ethanol also increased with the current density of the deposition, and again the highest was that for the electrode prepared at $40 \mathrm{~mA} / \mathrm{cm}^{2}$, a value of about $60 \mathrm{~mA} / \mathrm{cm}^{2}$ at about $+0.6 \mathrm{~V}$ (MMO). The oxidation process began at the potential where the Ni (III) species was formed, as shown by the cyclic voltammogram in Fig. 5(c).

To examine the influence of the introduction of $\mathrm{MgO}$ particles on the electrochemical features of the $\mathrm{Ni}$ composite electrode, cyclic voltammograms were recorded for the $\mathrm{Ni}-\mathrm{MgO} / \mathrm{C}$ electrode in the absence and presence of alcohol and compared with those for $\mathrm{Ni} / \mathrm{C}$ electrodes. The results obtained for the different $\mathrm{Ni}-\mathrm{MgO} / \mathrm{C}$ composite electrodes showed the appearance of similar electrochemical features with $\mathrm{MgO}$ particles introduction, but different catalytic activities. The $\mathrm{Ni}-\mathrm{MgO} / \mathrm{C}$ electrodes showed a relatively high catalytic activity in 1.0 mol/L $\mathrm{NaOH}$ compared with that of the $\mathrm{Ni} / \mathrm{C}$ electrodes. Fig. 6(a) represents the cyclic voltammetric response of the composite electrodes in $1.0 \mathrm{~mol} / \mathrm{L} \mathrm{NaOH}$ at a scan rate of $50 \mathrm{mV} / \mathrm{s}$ in the potential range from -0.5 to $+1.2 \mathrm{~V}$ (MMO). Also, the electrooxidation of $1.0 \mathrm{~mol} / \mathrm{L}$ methanol and $1.0 \mathrm{~mol} / \mathrm{L}$ ethanol in $1.0 \mathrm{~mol} / \mathrm{L} \mathrm{NaOH}$ at a scan rate of $50 \mathrm{mV} / \mathrm{s}$ at the $\mathrm{Ni}-\mathrm{MgO} / \mathrm{C}$ electrodes is represented in Fig. 6(b) and (c), respectively. It is clear from the blank cyclic voltammograms (Fig. 6(a)) that in $1.0 \mathrm{~mol} / \mathrm{L} \mathrm{NaOH}$ the $\mathrm{Ni}-\mathrm{MgO} / \mathrm{C}$ electrodes showed similar behavior to those of the $\mathrm{Ni} / \mathrm{C}$ electrodes, but with higher oxidation current densities of the Ni redox species. Therefore, the presence of $\mathrm{MgO}$ in the Ni matrix enhanced the formation of the $\mathrm{Ni}(\mathrm{II}) / \mathrm{Ni}(\mathrm{III})$ redox couple, resulting in the large enhancement in methanol and ethanol oxidation obtained at these electrodes. For the $\mathrm{Ni}-\mathrm{MgO} / \mathrm{C}$ electrode prepared at $40 \mathrm{~mA} / \mathrm{cm}^{2}$, the oxidation peak current density was about $196 \mathrm{~mA} / \mathrm{cm}^{2}$ for methanol and $179 \mathrm{~mA} / \mathrm{cm}^{2}$ for ethanol. The oxidation process began at $+0.5 \mathrm{~V}$ (MMO) and reached a peak potential of $+1.062 \mathrm{~V}$ (MMO) for methanol and $+0.977 \mathrm{~V}$ (MMO) for ethanol. Thus, the alcohol oxidation current density clearly increased in the presence of $\mathrm{MgO}$ (Table 3).

The role of the $\mathrm{MgO}$ particles in improving the catalytic activity of $\mathrm{Ni}$ is ascribed to their improved geometrical properties, namely, their ability to increase the real surface area of the $\mathrm{Ni}$ by decreasing its grain size, which consequently increased the number of active sites and the catalytic activity of the $\mathrm{Ni}$. Hence, its role is similar to that of $\mathrm{TiO}_{2}$ as reported in our previous work [6]. The magnitude of the enhancement compared with the activity of $\mathrm{Ni} / \mathrm{C}$, however, was on the order of 3 times when $12 \mathrm{wt} \%$ of $\mathrm{MgO}$ was included in the composite. It is most significant that the currents obtained with the $\mathrm{Ni}-\mathrm{MgO} / \mathrm{C}$ anode 

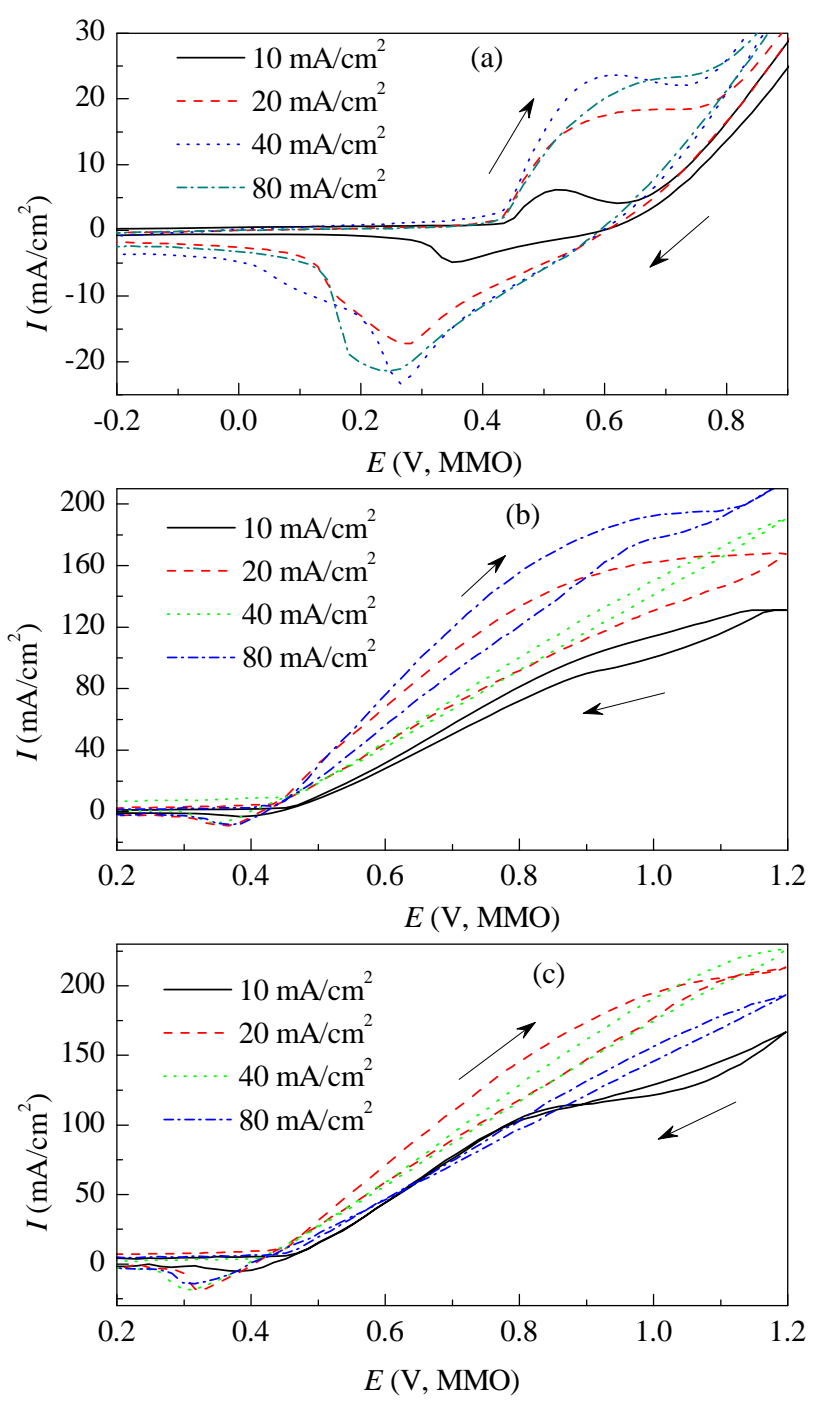

Fig. 6. Cyclic voltammograms of $\mathrm{Ni}-\mathrm{MgO} / \mathrm{C}$ prepared at different deposition current densities in $1.0 \mathrm{~mol} / \mathrm{L} \mathrm{NaOH} \mathrm{(a),} 1.0 \mathrm{~mol} / \mathrm{L} \mathrm{NaOH}+1.0$

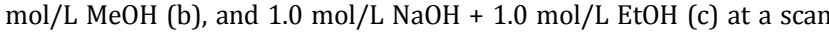
rate of $50 \mathrm{mV} / \mathrm{s}$.

were higher, likely caused by an increase in the electroactive area of the anode owing to the smaller and more well-dispersed $\mathrm{Ni}$ particles in the composite compared with those of the $\mathrm{Ni} / \mathrm{C}$ electrode, as reported elsewhere [46]. This led to the formation of a large amount of $\mathrm{NiOOH}$ active sites, which are

Table 3

The oxidation peak current density values, peak potentials for methanol and ethanol electrooxidation at $\mathrm{Ni} / \mathrm{C}$ and $\mathrm{Ni}-\mathrm{MgO} / \mathrm{C}$ electrodes.

\begin{tabular}{lcccccc}
\hline Electrode & $\begin{array}{c}\text { Deposition } \\
\text { current density } \\
\left(\mathrm{mA} / \mathrm{cm}^{2}\right)\end{array}$ & \multicolumn{2}{c}{ Methanol } & & \multicolumn{2}{c}{ Ethanol } \\
\cline { 3 - 4 } \cline { 6 - 7 } & $\left(\mathrm{mA} / \mathrm{cm}^{2}\right)$ & $\begin{array}{c}E_{\mathrm{p}} / \mathrm{mV} \\
(\mathrm{MMO})\end{array}$ & & $\begin{array}{c}I_{\mathrm{p}} \\
\left(\mathrm{mA} / \mathrm{cm}^{2}\right)\end{array}$ & $\begin{array}{c}E_{\mathrm{p}} / \mathrm{mV} \\
(\mathrm{MMO})\end{array}$ \\
\hline $\mathrm{Ni} / \mathrm{C}$ & 10 & 23.7 & +760 & & 9.0 & +624 \\
& 20 & 53 & +730 & & 20.2 & +610 \\
& 40 & 64 & +756 & & 36.4 & +608 \\
& 80 & 60 & +760 & & 22.9 & +610 \\
$\mathrm{Ni}-\mathrm{MgO} / \mathrm{C}$ & 10 & 118 & +1000 & & 128 & +1000 \\
& 20 & 161 & +1000 & & 192 & +1000 \\
& 40 & 192 & +1000 & & 196 & +1000 \\
& 80 & 151 & +1000 & & 158 & +1000 \\
\hline
\end{tabular}

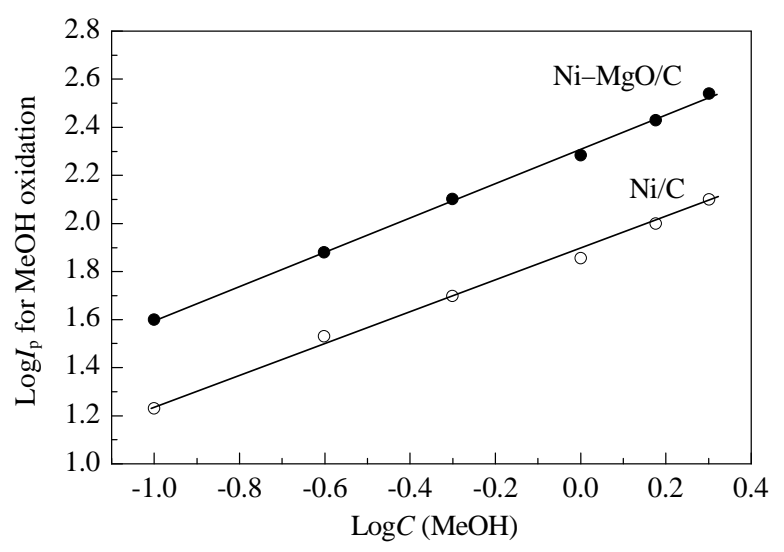

Fig. 7. The logarithmic relation between methanol concentration and the oxidation peak current density of $\mathrm{MeOH}$ at $\mathrm{Ni} / \mathrm{C}$ and $\mathrm{Ni}-\mathrm{MgO} / \mathrm{C}$ electrodes.

required for alcohol oxidation. The results of the electrooxidation of methanol and ethanol at the different prepared electrode catalysts are represented in Table 3. Another explanation for the role of $\mathrm{MgO}$ in enhancing the electrocatalytic activity of $\mathrm{Ni}$ could be the formation of $\mathrm{Mg}(\mathrm{OH})_{2}$ from $\mathrm{MgO}$ in the presence of water at a relatively high anodic potential. A metastable $\mathrm{MgO}_{2}$ species may have been formed from these species according to the Pourbaix diagram of Mg [47], and this would have aided in the oxidation of the alcohol.

The order of the methanol oxidation reaction on $\mathrm{Ni} / \mathrm{C}$ and $\mathrm{Ni}-\mathrm{MgO} / \mathrm{C}$ prepared at $40 \mathrm{~mA} / \mathrm{cm}^{2}$ was determined by plotting the logarithmic relationship between the current density of the forward peaks and methanol concentration, as shown in Fig. 7. The rate of the methanol oxidation reaction is related to the methanol concentration according to the following equation:

$$
\begin{gathered}
I_{\mathrm{p}}=k C^{n} \\
\log I_{\mathrm{p}}=\log k+n \log C
\end{gathered}
$$

where $I_{\mathrm{p}}$ is the peak current density, $k$ is the reaction rate constant, $C$ is the methanol concentration, and $n$ is the reaction order. Straight lines were obtained with slope values of 0.65 and 0.71 for the $\mathrm{Ni} / \mathrm{C}$ and $\mathrm{Ni}-\mathrm{MgO} / \mathrm{C}$ electrodes, respectively. We point out that the presence of MgO did not significantly affect the order of the methanol oxidation reaction at the surface of the different electrocatalysts.

Additionally, MgO possesses a good anti-poisoning ability, which was another factor that improved the efficiency of the oxidation process compared with that of $\mathrm{Ni} / \mathrm{C}$. The anti-poisoning ability of the catalyst may have been enhanced by the large amount of active sites for methanol or ethanol oxidation. The stability of the prepared samples was estimated using chronoamperometry. The $\mathrm{Ni}-\mathrm{MgO} / \mathrm{C}$ composite electrodes showed an improved performance toward the electrooxidation process with time compared with the $\mathrm{Ni} / \mathrm{C}$ catalyst. To estimate the stabilities of the various prepared electrodes toward the electrooxidation of methanol and ethanol, the results of chronoamperometric experiments on the $\mathrm{Ni} / \mathrm{C}$ and $\mathrm{Ni}-\mathrm{MgO} / \mathrm{C}$ composite electrodes prepared at $40 \mathrm{~mA} / \mathrm{cm}^{2}$ are presented in Fig. 8. The test was carried out by holding the potential at $+0.8 \mathrm{~V}$ (MMO) in $1.0 \mathrm{~mol} / \mathrm{L}$ methanol and in $1.0 \mathrm{~mol} / \mathrm{L}$ ethanol in the presence of $1.0 \mathrm{~mol} / \mathrm{L} \mathrm{NaOH}$ for about $900 \mathrm{~s}$. From Fig. 8, it is 


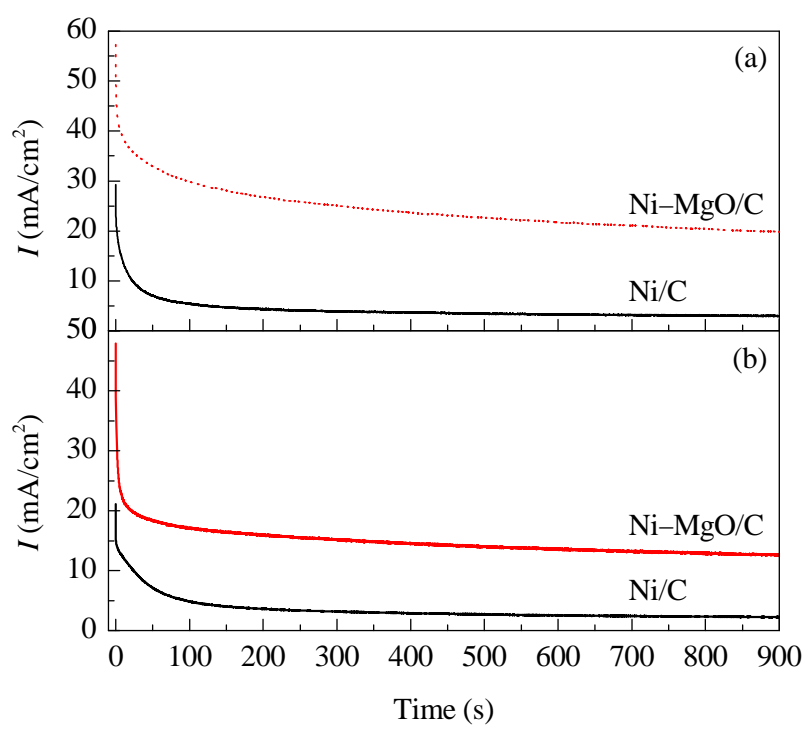

Fig. 8. Chronoamperometry results of $\mathrm{Ni} / \mathrm{C}$ and $\mathrm{Ni}-\mathrm{MgO} / \mathrm{C}$ electrodes in $1 \mathrm{~mol} / \mathrm{L} \mathrm{MeOH} \mathrm{(a)} \mathrm{and} 1 \mathrm{~mol} / \mathrm{L} \mathrm{EtOH} \mathrm{(b)} \mathrm{in} \mathrm{the} \mathrm{presence} \mathrm{of} 1.0 \mathrm{~mol} / \mathrm{L}$ $\mathrm{NaOH}$ at $+0.8 \mathrm{~V}$ (MMO).

clear that the stability of the composite $\mathrm{Ni}-\mathrm{MgO} / \mathrm{C}$ electrode in the electrooxidation process was much higher than that of the $\mathrm{Ni} / \mathrm{C}$ electrode. The $\mathrm{Ni}-\mathrm{MgO} / \mathrm{C}$ electrode delivered a high steady state oxidation current density and better stability than the $\mathrm{Ni} / \mathrm{C}$ electrode owing to the promoting effect and anti-poisoning ability of the MgO. This conclusion is consistent with the report by Liu et al. [24,30]. Although adding MgO enhanced the anti-poisoning stability of the Ni catalyst, the reac- tion mechanism did not change. In general, the decrease in the current density of methanol or ethanol oxidation at Ni-based electrodes with time has been attributed to a loss in activity of the nickel oxide $[48,49]$. The passive oxide $\gamma$-NiOOH may be formed under long polarization, blocking some of the electrode activity owing to its poor conducting behavior. Therefore, the presence of $\mathrm{MgO}$ in the $\mathrm{Ni}$ catalyst may have suppressed the formation of $\gamma-\mathrm{NiOOH}$ and enhanced $\beta-\mathrm{NiOOH}$ formation, which would have increased the catalytic activity and stability.

\section{3. $\quad$ EIS results}

EIS measurements were performed to further study the electrocatalytic performance of the synthesized $\mathrm{Ni}-\mathrm{MgO} / \mathrm{C}$ electrodes prepared at different deposition current densities in $1.0 \mathrm{~mol} / \mathrm{L} \mathrm{NaOH}$ solution in the absence and presence of 1.0 $\mathrm{mol} / \mathrm{L}$ methanol and $1.0 \mathrm{~mol} / \mathrm{L}$ ethanol. The results were compared with those obtained for $\mathrm{Ni} / \mathrm{C}$ electrodes prepared under the same experimental conditions. Fig. 9(a) and (b) show the Nyquist diagrams of the $\mathrm{Ni} / \mathrm{C}$ and $\mathrm{Ni}-\mathrm{MgO} / \mathrm{C}$ electrodes in 1.0 $\mathrm{mol} / \mathrm{L} \mathrm{NaOH}$ at a potential of $+0.45 \mathrm{~V}$. In Nyquist plots, the imaginary impedance $(Z)$ is plotted against the real impedance $(Z)$. The Nyquist plot of an impedance spectrum includes a semicircular portion and a linear portion. The semicircular portion at high frequency corresponds to the electron transfer limited process, and the linear portion at low frequency corresponds to the diffusion process. The diameter of the semicircle is equal to the charge transfer resistance at the electrode surface $\left(R_{\mathrm{ct}}\right)$ [50]. Thus, the diameter of the semicircle is dependent on the current density; the diameter decreases with in-
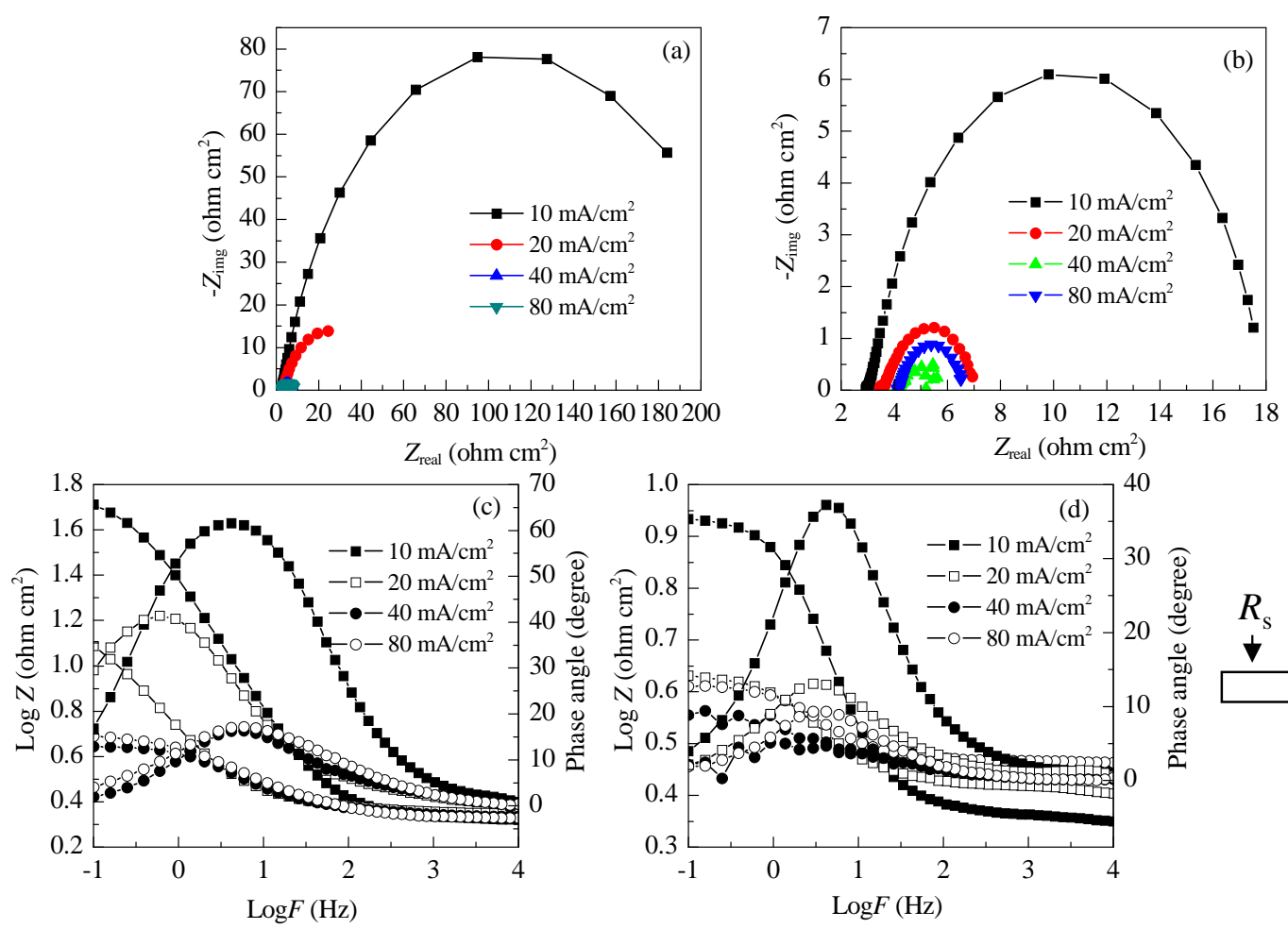

(e)

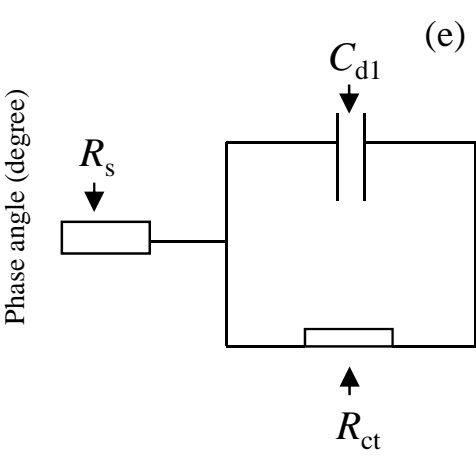

Fig. 9. Nyquist plots of $\mathrm{Ni} / \mathrm{C}$ (a) and $\mathrm{Ni}-\mathrm{MgO} / \mathrm{C}$ (b), Bode plots of $\mathrm{Ni} / \mathrm{C}$ (c) and $\mathrm{Ni}-\mathrm{MgO} / \mathrm{C}$ (d) electrocatalysts prepared at different deposition current densities in $1.0 \mathrm{~mol} / \mathrm{L} \mathrm{NaOH}$ at room temperature. Equivalent circuit that represents the behavior of $\mathrm{Ni} / \mathrm{C}$ and $\mathrm{Ni}-\mathrm{MgO} / \mathrm{C} \mathrm{in} 1.0 \mathrm{~mol} / \mathrm{L} \mathrm{NaOH} \mathrm{(e).}$ 
creasing current density. The lowest semicircle diameter was recorded at $40 \mathrm{~mA} / \mathrm{cm}^{2}$. It can be seen from Fig. 9(a) that a well-defined semicircle curve was obtained with the $\mathrm{Ni} / \mathrm{C}$ catalyst. After the electrode was modified with MgO, the diameter of the semicircle decreased. This result may be ascribed to the larger surface area obtained for the $\mathrm{Ni}-\mathrm{MgO} / \mathrm{C}$ electrodes compared with that of the $\mathrm{Ni} / \mathrm{C}$ electrodes, and the corresponding promoted electron transfer. The smallest semicircle was observed, suggesting that the presence of $\mathrm{MgO}$ decreased the resistance of the electrode and maintained a high electron transfer efficiency. It is worth mentioning that a low charge transfer resistance indicates a fast electron-transfer rate for an electrocatalyst and higher electrocatalytic activity [51]. Bode plots for the same samples are shown in Fig. 9(c) and (d). One distinguishable peak was observed in the Bode plots, which corresponded to the depressed semicircle in the Nyquist plot. The equivalent circuit compatible with the Nyquist diagram is depicted in Fig. 9(e). The equivalent circuit shows $R_{\mathrm{s}}, \mathrm{CPE}$, and $R_{\mathrm{ct}}$, which represent the solution resistance, a constant phase element corresponding to the double layer capacitance, and the charge-transfer resistance, respectively. Thales software provided with the Zahner Elektrik IM6 electrochemical workstation where the dispersion formula suitable to each model was used for the analysis [52]. To obtain a satisfactory impedance analysis, the capacitor $\mathrm{C}$ was replaced with a constant phase element (CPE) in the equivalent circuit. The most widely accepted explanation for the presence of CPE behavior and depressed semicircles for solid electrodes is the microscopic roughness causing an inhomogeneous distribution in the solution resistance as well as in the double-layer capacitance [53].

The experimental values are correlated with the theoretical impedance parameters of the equivalent model in Table 4. The impedance $\left(Z_{\mathrm{CPE}}\right)$ of a constant phase element is defined as:

$$
Z_{\mathrm{CPE}}=\left[C(\mathrm{j} w)^{\alpha}\right]^{-1}
$$

where $-1 \leq \alpha \leq 1, j=(-1)^{1 / 2}, w=2 \pi f$ is the angular frequency in $\mathrm{rad} / \mathrm{s}, f$ is the frequency in $\mathrm{Hz}=\mathrm{s}^{-1}$, and $\alpha$ is a fitting parameter which is an empirical exponent varying between 1 for a perfect capacitor and 0 for a perfect resistor. In this complex formula, the empirical exponent $\alpha$ is introduced to account for the deviation from the ideal capacitive behavior caused by surface heterogeneity, the roughness factor, and adsorption effects
Table 4

Electrochemical impedance parameters of $\mathrm{Ni} / \mathrm{C}$ and $\mathrm{Ni}-\mathrm{MgO} / \mathrm{C}$ electrocatalysts prepared at different deposition current densities in 1.0 $\mathrm{mol} / \mathrm{L} \mathrm{NaOH}$ solution.

\begin{tabular}{lcccccc}
\hline Catalyst & $\begin{array}{c}I \\
\left(\mathrm{~mA} / \mathrm{cm}^{2}\right)\end{array}$ & $R_{\mathrm{s}} / \Omega$ & $\begin{array}{c}\mathrm{CPE} \\
\left(\mu \mathrm{F} / \mathrm{cm}^{-2}\right)\end{array}$ & $\alpha$ & $\begin{array}{c}R_{\mathrm{ct}} \\
\left(\mathrm{k} \Omega \mathrm{cm}^{2}\right)\end{array}$ & $R_{\mathrm{F}}$ \\
\hline $\mathrm{Ni} / \mathrm{C}$ & 10 & 3.01 & 0.89 & 0.75 & 1.58 & 0.044 \\
& 20 & 2.70 & 1.33 & 0.70 & 1.43 & 0.066 \\
& 40 & 2.00 & 3.33 & 0.80 & 1.31 & 0.166 \\
& 80 & 2.30 & 2.13 & 0.70 & 1.20 & 0.115 \\
$\mathrm{Ni}-\mathrm{MgO} / \mathrm{C}$ & 10 & 4.50 & 3.20 & 0.85 & 0.94 & 0.16 \\
& 20 & 4.00 & 4.80 & 0.73 & 0.87 & 0.24 \\
& 40 & 3.00 & 8.40 & 0.77 & 0.53 & 0.42 \\
& 80 & 3.50 & 7.73 & 0.78 & 0.68 & 0.38 \\
\hline
\end{tabular}

$[51,53]$. In all cases, good agreement between theoretical and experimental data was obtained for the whole frequency range, with an average error of $2 \%$. The estimated parameters are given in Tables 4 and 5. The $\alpha$ values obtained from the fitting procedures for the $\mathrm{Ni} / \mathrm{C}$ and $\mathrm{Ni}-\mathrm{MgO} / \mathrm{C}$ electrodes ranged between 0.65 and 0.85 . This means that neither electrode behaved as a perfect capacitor.

Figure 10(a) and (b) show the Nyquist plots for $\mathrm{Ni} / \mathrm{C}$ and $\mathrm{Ni}-\mathrm{MgO} / \mathrm{C}$ electrodes, respectively, prepared at the optimum deposition current density of $40 \mathrm{~mA} / \mathrm{cm}^{2}$ in $1.0 \mathrm{~mol} / \mathrm{L} \mathrm{NaOH}$ for methanol electrooxidation at different potentials in 1.0 mol/L methanol. Before recording each impedance spectrum at a preselected DC potential, the working electrode was first held at this potential for $300 \mathrm{~s}$ to equilibrate. The magnitude of the diameter of the semicircle was strongly related to the anode potential in the methanol oxidation region. The corresponding resistance decreased with increasing potential. The decrease can be ascribed to methanol electrooxidation, as expected from previous cyclic voltammetry studies [54-57]. The Nyquist diagram consisted of two slightly depressed capacitive semicircles at high and low frequency. The depressed semicircle in the high frequency region may be related to the combination of the charge transfer resistance and the double layer capacitance. The low frequency semicircle was related to the adsorption of reaction intermediates on the electrode surface. A semicircle with a diameter dependent on the applied potential was ob-

Table 5

Electrochemical impedance parameters of $\mathrm{Ni} / \mathrm{C}$ electrocatalyst prepared at different deposition current densities in $1.0 \mathrm{~mol} / \mathrm{L} \mathrm{NaOH}+1.0 \mathrm{~mol} / \mathrm{L}$ methanol solution at different applied potentials.

\begin{tabular}{|c|c|c|c|c|c|c|c|c|c|c|}
\hline$I /\left(\mathrm{mA} / \mathrm{cm}^{2}\right)$ & Potential $(\mathrm{mV})$ & $R_{\mathrm{s}} / \Omega$ & $\mathrm{CPE}\left(\mu \mathrm{F} / \mathrm{cm}^{2}\right)$ & $\alpha 1$ & $R_{\mathrm{ct}} /\left(\mathrm{k} \Omega \mathrm{cm}^{2}\right)$ & $\mathrm{CPE}_{\text {ads }}\left(\mu \mathrm{F} / \mathrm{cm}^{2}\right)$ & $\alpha 2$ & $R_{\text {ads }} /\left(\mathrm{k} \Omega \mathrm{cm}^{2}\right)$ & $W /\left(\Omega \mathrm{s}^{-1 / 2}\right)$ & $R_{\mathrm{F}}$ \\
\hline \multirow[t]{3}{*}{10} & 500 & 1.30 & 76.9 & 0.60 & 0.149 & - & - & - & - & 3.8 \\
\hline & 600 & 1.20 & 93.3 & 0.65 & 0.034 & - & - & - & - & 4.7 \\
\hline & 700 & 1.20 & 97.1 & 0.65 & 0.004 & - & - & - & - & 4.9 \\
\hline \multirow[t]{3}{*}{20} & 500 & 1.90 & 93.2 & 0.65 & 0.024 & 1650.3 & 0.75 & 5.70 & 180.5 & 4.7 \\
\hline & 600 & 1.70 & 100.2 & 0.65 & 0.027 & 1733.3 & 0.70 & 4.88 & 173.1 & 5.0 \\
\hline & 700 & 2.80 & 103.5 & 0.60 & 0.030 & 2533.3 & 0.60 & 0.63 & 16.6 & 5.2 \\
\hline \multirow[t]{3}{*}{40} & 500 & 3.10 & $0.7 \times 10^{3}$ & 0.90 & 0.019 & $2.2 \times 10^{3}$ & 0.65 & 0.70 & 59.6 & 35 \\
\hline & 600 & 2.80 & $1.1 \times 10^{3}$ & 0.85 & 0.007 & $3.2 \times 10^{3}$ & 0.70 & 0.20 & 148.4 & 50 \\
\hline & 700 & 2.80 & $1.7 \times 10^{3}$ & 0.90 & 0.006 & $28.3 \times 10^{3}$ & 0.60 & 0.10 & 10.06 & 85 \\
\hline \multirow[t]{3}{*}{80} & 500 & 3.10 & 117.7 & 0.78 & 0.003 & $4.7 \times 10^{3}$ & 0.60 & 0.75 & 158.4 & 5.9 \\
\hline & 600 & 3.10 & 127.1 & 0.81 & 0.002 & $18.6 \times 10^{3}$ & 0.60 & 0.35 & 24.3 & 6.4 \\
\hline & 700 & 3.10 & 127.1 & 0.80 & 0.002 & $22.2 \times 10^{3}$ & 0.60 & 0.13 & 12.64 & 6.4 \\
\hline
\end{tabular}



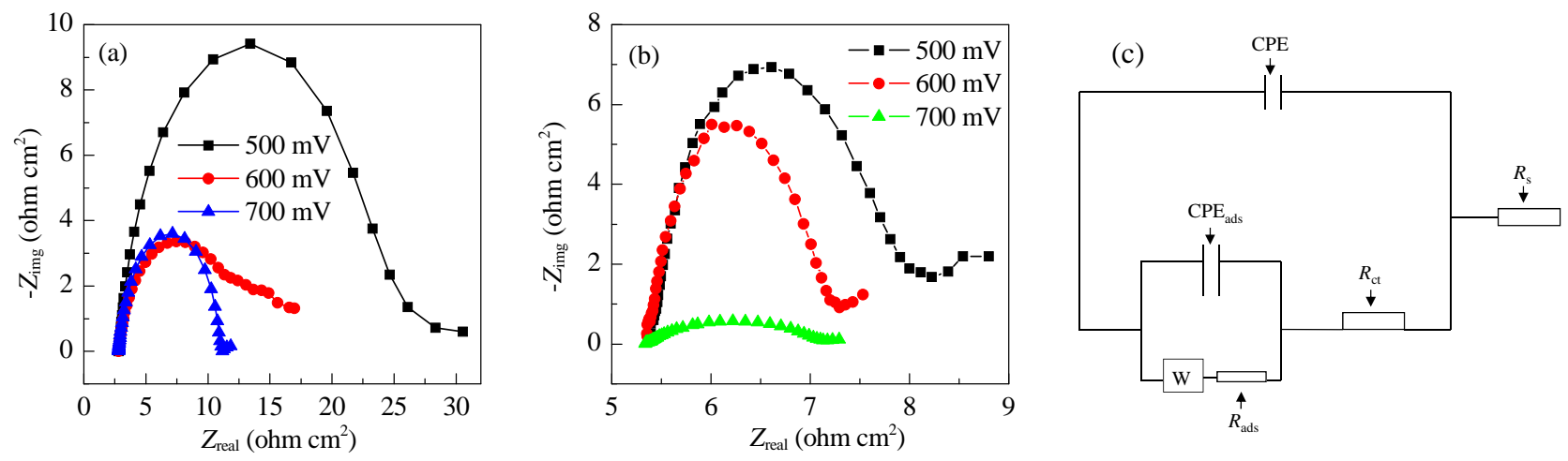

Fig. 10. Nyquist plots of $\mathrm{Ni} / \mathrm{C}(\mathrm{a})$ and $\mathrm{Ni}-\mathrm{MgO} / \mathrm{C}$ (b) electrocatalysts prepared at $40 \mathrm{~mA} / \mathrm{cm}^{2}$ in $1.0 \mathrm{~mol} / \mathrm{L} \mathrm{NaOH}+1.0 \mathrm{~mol} / \mathrm{L}$ methanol at different applied potentials at room temperature. (c) Equivalent circuit that represents the behavior of $\mathrm{Ni} / \mathrm{C}$ and $\mathrm{Ni}-\mathrm{MgO} / \mathrm{C}$ towards electrooxidation of $\mathrm{MeOH}$ and $\mathrm{EtOH}$ in $1.0 \mathrm{~mol} / \mathrm{L} \mathrm{NaOH}$.

served. The diameter decreased as the potential was increased from $0.5-0.7 \mathrm{~V}$, and consequently, the conductivity increased. The equivalent circuit is presented in Fig. 10(c), in which another parallel combination of CPEads and Rads and Warburg impedance has been added to the simple Randless cell. CPE ads and $R_{\text {ads }}$ are the electrical elements related to the adsorption of the reaction intermediates, while the Warburg impedance is related to the diffusion of adsorbed intermediates toward active sites. In this circuit, the charge transfer resistance of the electrode reaction is the circuit element, which has a simple physical meaning describing how fast the rate of charge transfer during methanol electrooxidation changes with the electrode potential when the surface coverage of the intermediates is held constant. Increasing the potential was found to decrease the impedance of both electrodes. Meanwhile, the conductivity of the $\mathrm{Ni}-\mathrm{MgO} / \mathrm{C}$ electrode was remarkably higher than that of the Ni/C electrode, as seen from the $R_{\text {ads }}$ and $R_{\mathrm{ct}}$ values in Tables 6 and 7.

The electrooxidation of $1.0 \mathrm{~mol} / \mathrm{L}$ ethanol on the two electrodes prepared at $40 \mathrm{~mA} / \mathrm{cm}^{2}$ exhibited similar features to that of methanol. The corresponding Nyquist plots are shown in Fig. 11(a) and (b). The $\mathrm{Ni}-\mathrm{MgO} / \mathrm{C}$ electrode showed a much lower impedance than the $\mathrm{Ni} / \mathrm{C}$ electrode. Because the charge transfer resistance $\left(R_{\mathrm{ct}}\right)$ is inversely related to the charge transfer reaction kinetics, the ethanol oxidation reaction was expected to take place at a considerably higher rate. As shown in Fig. 11, the diameter of the depressed arc decreased rapidly with the increase of anodic potential, indicating that the charge transfer resistance for ethanol electrooxidation became smaller. Analysis of the impedance data at different potentials showed evidence for two processes occurring at the interface: one is associated with the formation of intermediates on the surface during methanol or ethanol electrooxidation, and the other is assigned to the oxidation of these intermediates. The double layer capacitance $\left(C_{\mathrm{dl}}\right)$ values, shown in Tables $4-8$, were estimated using the following relation:

$$
\mathrm{CPE}=C_{\mathrm{dl}}{ }^{n}\left(R_{\mathrm{s}}^{-1} R_{\mathrm{ct}}{ }^{-1}\right)^{1-n}
$$

Eq. (4) is used to compute $C_{\mathrm{dl}}$, when the CPE is coupled with the charge transfer process [58]. The electrode roughness $\left(R_{\mathrm{F}}=\right.$ observed $C_{\mathrm{dl}} / C_{\mathrm{dl}}$ for the smooth surface) given in Tables 4-8 was estimated based on a $C_{\mathrm{dl}}$ of $20 \mu \mathrm{F} / \mathrm{cm}^{2}$ for the smooth $\mathrm{Ni}$ surface [59]. The $R_{\mathrm{F}}$ value for the $\mathrm{Ni}-\mathrm{MgO} / \mathrm{C}$ electrode was found to be greater than that for the $\mathrm{Ni} / \mathrm{C}$ electrode (cf. Tables 4-8), which was, in fact, expected from the SEM observations (cf. Fig. 3) and electrochemical impedance measurements. Thus, the observed enhanced electrocatalytic activity of the $\mathrm{Ni}-\mathrm{MgO} / \mathrm{C}$ electrode arose from the enhanced roughness of the dispersed $\mathrm{Ni}$. The impedance results are comparable to the results obtained from the CVs of both electrodes for methanol and ethanol oxidation at different applied potentials.

Different mechanisms have been proposed in the literature for the oxidation of alcohols at nickel electrodes covered by

Table 6

Electrochemical impedance parameters of $\mathrm{Ni}-\mathrm{MgO} / \mathrm{C}$ electrocatalyst prepared at different deposition current densities in $1.0 \mathrm{~mol} / \mathrm{L} \mathrm{NaOH}+1.0$ $\mathrm{mol} / \mathrm{L}$ methanol solution at different applied potentials.

\begin{tabular}{lcccccrcccc}
\hline$I /\left(\mathrm{mA} / \mathrm{cm}^{2}\right)$ & Potential $(\mathrm{mV})$ & $R_{\mathrm{s}} / \Omega$ & $\mathrm{CPE}\left(\mu \mathrm{F} / \mathrm{cm}^{2}\right)$ & $\alpha 1$ & $R_{\mathrm{ct}} /\left(\mathrm{k} \Omega \mathrm{cm}^{2}\right)$ & $\mathrm{CPE}_{\mathrm{ads}}\left(\mu \mathrm{F} / \mathrm{cm}^{2}\right)$ & $\alpha 2$ & $R_{\mathrm{ads}} /\left(\mathrm{k} \Omega \mathrm{cm}^{2}\right)$ & $W /\left(\Omega \mathrm{s}^{-1 / 2}\right)$ & $R_{\mathrm{F}}$ \\
\hline 10 & 500 & 3.1 & 100.9 & 0.84 & 0.08 & 13.8 & 0.60 & 0.08 & 296.3 & 5.0 \\
& 600 & 3.2 & 105.5 & 0.80 & 0.05 & 23.5 & 0.65 & 0.04 & 133.5 & 5.2 \\
& 700 & 3.2 & 107.3 & 0.84 & 0.04 & 34.6 & 0.70 & 0.03 & 120.8 & 5.4 \\
20 & 500 & 3.8 & 150.1 & 0.75 & 0.07 & 848.4 & 0.80 & 0.05 & 2.5 & 7.5 \\
& 600 & 3.8 & 200.3 & 0.77 & 0.06 & 1261.8 & 0.75 & 0.03 & 1.5 & 10 \\
& 700 & 3.8 & 300.1 & 0.80 & 0.03 & 1169.2 & 0.75 & 0.02 & 1.5 & 15 \\
40 & 500 & 4.5 & $2.2 \times 10^{3}$ & 0.65 & 0.01 & 729.3 & 0.74 & 0.015 & 770.2 & 110 \\
& 600 & 4.5 & $2.5 \times 10^{3}$ & 0.69 & 0.01 & 813.3 & 0.77 & 0.014 & 844.3 & 125 \\
& 700 & 4.5 & $2.9 \times 10^{3}$ & 0.70 & 0.005 & 968.2 & 0.75 & 0.012 & 1220 & 145 \\
80 & 500 & 4.6 & 461.0 & 0.71 & 0.03 & 640.4 & 0.74 & 0.023 & 0.7 & 23.1 \\
& 600 & 4.6 & 815.1 & 0.70 & 0.02 & 737.7 & 0.71 & 0.022 & 0.9 & 40.7 \\
& 700 & 4.5 & 1169.7 & 0.65 & 0.015 & 856.9 & 0.77 & 0.022 & 2.5 & 58.5 \\
\hline
\end{tabular}


Table 7

Electrochemical impedance parameters of $\mathrm{Ni} / \mathrm{C}$ electrocatalyst prepared at different deposition current densities in $1.0 \mathrm{~mol} / \mathrm{L} \mathrm{NaOH}+1.0 \mathrm{~mol} / \mathrm{L}$ ethanol solution at different applied potentials.

\begin{tabular}{|c|c|c|c|c|c|c|c|c|c|c|}
\hline$I /\left(\mathrm{mA} / \mathrm{cm}^{2}\right)$ & Potential (mV) & $R_{\mathrm{S}} / \Omega$ & $\mathrm{CPE}\left(\mu \mathrm{F} / \mathrm{cm}^{2}\right)$ & $\alpha 1$ & $R_{\mathrm{ct}} /\left(\mathrm{k} \Omega \mathrm{cm}^{2}\right)$ & $\mathrm{CPE}_{\text {ads }}\left(\mu \mathrm{F} / \mathrm{cm}^{2}\right)$ & $\alpha 2$ & $R_{\mathrm{ads}} /\left(\mathrm{k} \Omega \mathrm{cm}^{2}\right)$ & $W /\left(\Omega \mathrm{s}^{-1 / 2}\right)$ & $R_{\mathrm{F}}$ \\
\hline \multirow[t]{3}{*}{10} & 500 & 2.40 & 81.3 & 0.70 & 1.43 & - & - & - & - & 4.0 \\
\hline & 600 & 2.50 & 140.2 & 0.65 & 0.50 & - & - & - & - & 7.0 \\
\hline & 700 & 2.50 & 156.2 & 0.65 & 0.30 & - & - & - & - & 7.8 \\
\hline \multirow[t]{3}{*}{20} & 500 & 3.70 & 97.6 & 0.62 & 0.08 & $10.4 \times 10^{3}$ & 0.65 & 0.90 & 1.7 & 4.9 \\
\hline & 600 & 2.90 & 118.3 & 0.80 & 0.07 & $10.5 \times 10^{3}$ & 0.85 & 0.11 & 35.5 & 5.9 \\
\hline & 700 & 3.80 & 160.8 & 0.70 & 0.06 & $45.3 \times 10^{3}$ & 0.70 & 0.10 & 10.5 & 8.0 \\
\hline \multirow[t]{3}{*}{40} & 500 & 2.50 & $1.1 \times 10^{3}$ & 0.82 & 0.012 & $2.3 \times 10^{3}$ & 0.65 & 0.32 & 165.4 & 50 \\
\hline & 600 & 2.50 & $1.7 \times 10^{3}$ & 0.80 & 0.01 & $2.9 \times 10^{3}$ & 0.60 & 0.20 & 154.6 & 85 \\
\hline & 700 & 2.50 & $2.1 \times 10^{3}$ & 0.86 & 0.005 & $3.3 \times 10^{3}$ & 0.60 & 0.07 & 50.5 & 105 \\
\hline \multirow[t]{3}{*}{80} & 500 & 2.90 & 122.4 & 0.75 & 0.03 & $2.4 \times 10^{3}$ & 0.55 & 0.62 & 26.9 & 6.1 \\
\hline & 600 & 2.90 & 114.9 & 0.80 & 0.02 & $4.4 \times 10^{3}$ & 0.60 & 0.40 & 14.8 & 5.7 \\
\hline & 700 & 2.90 & 175.5 & 0.84 & 0.01 & $15.3 \times 10^{3}$ & 0.65 & 0.30 & 12.8 & 8.8 \\
\hline
\end{tabular}

$\mathrm{Ni}(\mathrm{OH})_{2}$ in alkaline solution. In the case of the oxidation of alcohols in $1.0 \mathrm{~mol} / \mathrm{L} \mathrm{KOH}$ on a nickel electrode covered by $\mathrm{Ni}(\mathrm{OH})_{2}$, Fleischmann et al. [44,60] suggested that the $\mathrm{NiOOH}$ acts as an electrocatalyst. Other authors [61] have reported that methanol oxidation takes place after the complete oxidation of $\mathrm{Ni}(\mathrm{OH})_{2}$ to $\mathrm{NiOOH}$. El-Shafei [62] studied the oxidation of methanol on a nickel hydroxide/glassy carbon modified electrode in alkaline medium and found that methanol oxidation occurred via $\mathrm{Ni}^{3+}$ species (mainly $\mathrm{NiOOH}$ ). The redox transition of the $\mathrm{Ni}^{2+} / \mathrm{Ni}^{3+}$ couple is [63]:

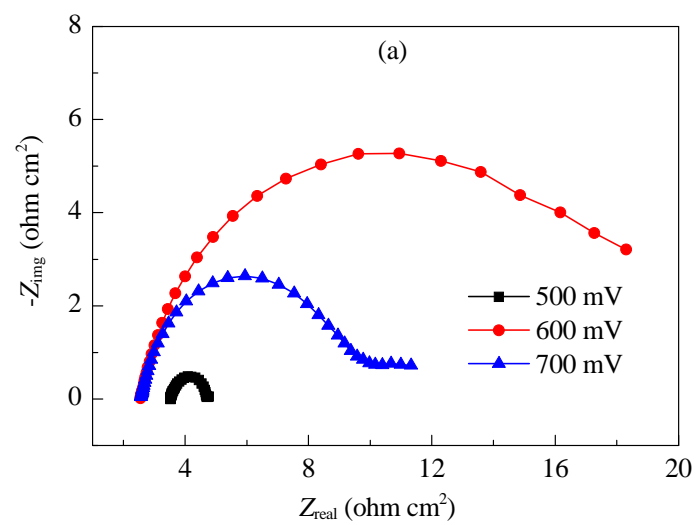

$$
\mathrm{Ni}^{2+} \rightarrow \mathrm{Ni}^{3+}+\mathrm{e}^{-}
$$

In this work, $\mathrm{Ni}(\mathrm{OH})_{2}$ species were transformed to $\mathrm{NiOOH}$ based on the following equation:

$$
\mathrm{Ni}(\mathrm{OH})_{2}+\mathrm{OH}^{-} \leftrightarrow \mathrm{NiOOH}+\mathrm{H}_{2} \mathrm{O}+\mathrm{e}^{-}
$$

Then, the alcohol (methanol/ethanol) was oxidized on the modified surface of the $\mathrm{Ni}-\mathrm{MgO} / \mathrm{C}$ via the following reaction:

$$
\begin{aligned}
\mathrm{Ni}^{3+}+\text { alcohol } & \rightarrow \mathrm{Ni}^{3+}+\text { intermediate }+\mathrm{e}^{-} \\
\mathrm{Ni}^{3+}+\text { intermediate } & \rightarrow \mathrm{Ni}^{3+}+\text { products }+\mathrm{e}^{-}
\end{aligned}
$$

In the above equations $\mathrm{Ni}^{3+}$-alcohol $\left(\mathrm{Ni}^{3+}\right.$-methanol/ethanol) and $\mathrm{Ni}^{3+}$-intermediates signify species adsorbed on $\mathrm{Ni}$

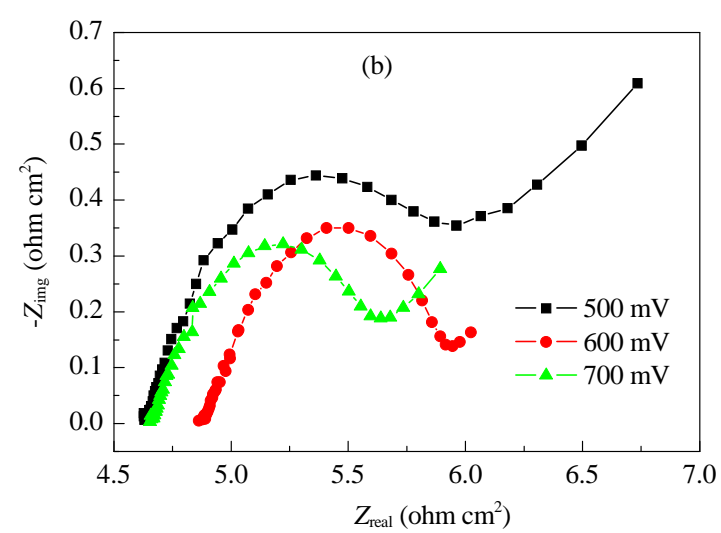

Fig. 11. Nyquist plots of $\mathrm{Ni} / \mathrm{C} \mathrm{(a)} \mathrm{and} \mathrm{Ni}-\mathrm{MgO} / \mathrm{C}$ (b) electrocatalysts prepared at $40 \mathrm{~mA} / \mathrm{cm}^{2}$ in $1.0 \mathrm{~mol} / \mathrm{L} \mathrm{NaOH}+1.0 \mathrm{~mol} / \mathrm{L}$ ethanol at different applied potentials at room temperature.

Table 8

Electrochemical impedance parameters of $\mathrm{Ni}-\mathrm{MgO} / \mathrm{C}$ electrocatalyst prepared at different deposition current densities in $1.0 \mathrm{~mol} / \mathrm{L} \mathrm{NaOH}+1.0$ $\mathrm{mol} / \mathrm{L}$ ethanol solution at different applied potentials.

\begin{tabular}{lcccccccccc}
\hline$I /\left(\mathrm{mA} / \mathrm{cm}^{2}\right)$ & Potential $(\mathrm{mV})$ & $R_{\mathrm{s}} / \Omega$ & $\mathrm{CPE}\left(\mu \mathrm{F} / \mathrm{cm}^{2}\right)$ & $\alpha 1$ & $R_{\mathrm{ct}} /\left(\mathrm{k} \Omega \mathrm{cm}^{2}\right)$ & $\mathrm{CPE}_{\text {ads }}\left(\mu \mathrm{F} / \mathrm{cm}^{2}\right)$ & $\alpha 2$ & $R_{\mathrm{ads}} /\left(\mathrm{k} \Omega \mathrm{cm}^{2}\right)$ & $W /\left(\Omega \mathrm{s}^{-1 / 2}\right)$ & $R_{\mathrm{F}}$ \\
\hline 10 & 500 & 4.2 & 158.93 & 0.77 & 0.09 & $18.9 \times 10^{3}$ & 0.85 & 0.23 & 75.2 & 7.9 \\
& 600 & 4.3 & 173.33 & 0.75 & 0.08 & $28.9 \times 10^{3}$ & 0.85 & 0.200 & 9.6 & 8.7 \\
& 700 & 4.3 & 176.80 & 0.78 & 0.06 & $54.2 \times 10^{3}$ & 0.80 & 0.005 & 4.6 & 8.8 \\
20 & 500 & 4.6 & 459.7 & 0.72 & 0.05 & 213.3 & 0.70 & 0.15 & 1.2 & 23.0 \\
& 600 & 4.7 & 536.5 & 0.65 & 0.045 & 1014.7 & 0.71 & 0.03 & 1.1 & 26.8 \\
& 700 & 5.3 & 645.4 & 0.70 & 0.03 & 1382.6 & 0.69 & 0.03 & 664.7 & 32.3 \\
40 & 500 & 4.1 & 1148.1 & 0.65 & 0.015 & 828.3 & 0.75 & 0.015 & 0.9 & 57.4 \\
& 600 & 3.9 & 1313.3 & 0.74 & 0.015 & $1.6 \times 10^{3}$ & 0.72 & 0.013 & 1.4 & 65.7 \\
& 700 & 4.6 & $5.0 \times 10^{3}$ & 0.65 & 0.010 & $2.2 \times 10^{3}$ & 0.80 & 0.012 & 1.6 & 250 \\
80 & 500 & 4.5 & $2.2 \times 10^{3}$ & 0.65 & 0.05 & $2.1 \times 10^{3}$ & 0.71 & 0.13 & 1.4 & 110 \\
& 600 & 4.5 & $2.4 \times 10^{3}$ & 0.66 & 0.04 & $1.6 \times 10^{3}$ & 0.65 & 0.019 & 4.3 & 120 \\
& 700 & 4.5 & $2.4 \times 10^{3}$ & 0.71 & 0.02 & 1256.3 & 0.70 & 0.018 & 20.1 & 120 \\
\hline
\end{tabular}


sites. $\mathrm{Ni}^{3+}$ species were used as the active surface for alcohol oxidation. A larger amount of $\mathrm{Ni}(\mathrm{III}) /(\mathrm{II})$ species formed on the $\mathrm{Ni}-\mathrm{MgO} / \mathrm{C}$ electrode compared with on the $\mathrm{Ni} / \mathrm{C}$ electrode (cf Figs. 5 and 6). Apparently, as the potential is increased, large amounts of $\mathrm{Ni}^{3+}$ are formed on the electrode surface and react with intermediates to decrease their coverage, which also results in a higher number of active sites available for reactions (III) and (IV). This is clear from the impedance results (cf. Figs. 10 and 11) where, the diameter of the depressed arc of the Nyquist plots decreased rapidly as the anodic potential was increased, indicating that the charge transfer resistance for ethanol/methanol electrooxidation became smaller.

\section{Conclusions}

$\mathrm{Ni}-\mathrm{MgO} / \mathrm{C}$ electrodes were successfully prepared by a facile electrodeposition technique. Increasing the current density caused the rate of the co-deposition process to increase, and the optimum deposition current density was found to be 40 $\mathrm{mA} / \mathrm{cm}^{2}$. Scanning electron microscopy analysis revealed that the presence of $\mathrm{MgO}$ particles in the deposit reduced the size of the $\mathrm{Ni}$ grains and resulted in refinement of the surface. The $\mathrm{Ni}-\mathrm{MgO} / \mathrm{C}$ electrodes exhibited a higher oxidation current density and efficiency towards methanol and ethanol electrooxidation compared with $\mathrm{Ni} / \mathrm{C}$ electrodes. The results of EIS confirmed those of the $\mathrm{CV}$ measurements, and revealed a lower charge transfer resistance and enhanced roughness for the $\mathrm{Ni}-\mathrm{MgO} / \mathrm{C}$ nano-composite electrodes. Owing to their enhanced performance, facile synthesis, and low cost, these catalysts deserve closer attention as promising candidates for possible application as anode materials in alkaline fuel cells.

\section{References}

[1] J. C. Amphlett, B. A. Peppley, E. Halliop, A. Sadiq, J. Power Sources, 2001, 96, 204-213.
[2] V. M. Barragan, A. Heinzel, J. Power Sources, 2002, 104, 66-72.

[3] V. Comignani, J. M. Sieben, M. E. Brigante, M. M. E. Duarte, J. Power Sources, 2015, 278, 119-127.

[4] V. A. Kazakov, V. N. Titova, A. A. Yavich, N. V. Petrova, M. R. Tarasevich, Russ. J. Electrochem., 2004, 40, 679-682.

[5] M. R. Tarasevich, Z. R. Karichev, V. A. Bogdanovskaya, A. V. Kapustin, E. N. Lubnin, M. A. Osina, Russ. J. Electrochem., 2005, 41, 736-745.

[6] L. M. Yang, D. F. Yan, C. B. Liu, H. J. Song, Y. H. Tang, S. L. Luo, M. J. Liu, J. Power Sources, 2015, 278, 725-732.

[7] A. Abdel Aal, H. B. Hassan, J. Alloy. Compd., 2009, 477, 652-656.

[8] N. Sattarahmady, H. Heli, F. Faramarzi, Talanta, 2010, 82, 1126-1135.

[9] L. Zhang, F. Li, Appl. Clay Sci., 2010, 50, 64-72.

[10] B. P. Lu, J. Bai, X. J. Bo, L. D. Zhu, L. P. Gu, Electrochim. Acta, 2010, 55, 8724-8730.

[11] H. B. Hassan, Z. Abdel Hamid, Int. J. Hydrogen Energy, 2011, 36, 849-856.

[12] H. B. Hassan, Z. Abdel Hamid, Surf. Interface Anal., 2013, 45, 11351143.

[13] H. B. Hassan, M. A. Abdel Rahim, M. W. Khalil, R. F. Mohammed, Int. J. Electrochem. Sci., 2014, 9, 760-777.

[14] E. Antolini, E. R. Gonzalez, J. Power Sources, 2010, 195, 34313450.

[15] A. J. Motheo, G. Tremiliosi-Filho, E. R. Gonzalez, K. B. Kokoh, J. M. Leger, C. Lamy, J. Appl. Electrochem., 2006, 36, 1035-1041.

[16] M. A. Abdel Rahim, R. M. Abdel Hameed, M. W. Khalil, J. Power Sources, 2004, 134, 160-169.

[17] Y. H. Qin, Y. F. Li, R. L. Lv, T. L. Wang, W. G. Wang, C. W. Wang, J. Power Sources, 2015, 278, 639-644.

[18] H. B. Hassan, Z. Abdel Hamid, M. Hassan, Surf. Interface Anal., 2014, 46, 512-520.

[19] Y. Wang, Z. Xu, Surf. Coat. Technol., 2006, 200, 3896-3902.

[20] A. Abdel Aal, K. M. Ibrahim, Z. Abdel Hamid, Wear, 2006, 260, 1070-1075.

[21] A. Abdel Aal, M. A. Barakat, R. M. Mohamed, Appl. Surf. Sci., 2008, 254, 4577-4583.

[22] A. Abdel Aal, Mater. Sci. Eng. A, 2008, 474, 181-187.

[23] H. B. Hassan, Z. Abdel Hamid, Int. J. Hydrogen Energy, 2011, 36,

\section{Graphical Abstract}

Chin. J. Catal., 2016, 37: 616-627 doi: 10.1016/S1872-2067(15)61034-8

\section{Electrooxidation of methanol and ethanol on carbon electrodeposited $\mathrm{Ni}-\mathrm{MgO}$ nanocomposite}

H. B. Hassan*, Z. Abdel Hamid*, Rabab M. El-Sherif Cairo University, Egypt; Central Metallurgical Research and Development Institute, Egypt
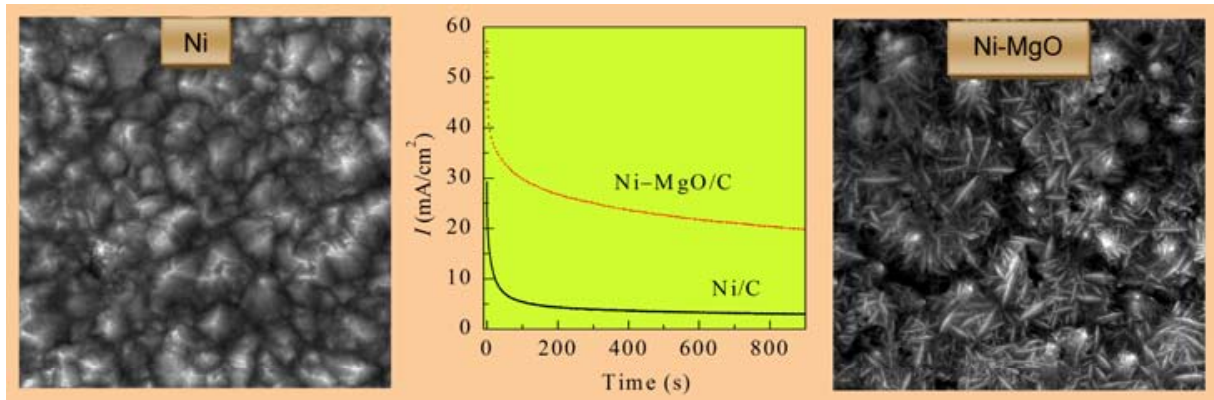

This work presents the research progress of direct alcohol fuel cell especially the anode catalyst. Ni-MgO/C in nano-sized was prepared as a novel anode for electrooxidation of alcohol and it showed enhanced performance and stability. 
5117-5127.

[24] C. W. Xu, Z. Q. Tian, P. K. Shen, S. P. Jiang, Electrochim. Acta, 2008, $53,2610-2618$.

[25] C. Kacar, B. Dalkiran, P. E. Erden, E. Kilic, Appl. Surf. Sci., 2014, 311, 139-146.

[26] R. Suresh, K. Giribabu, R. Manigandan, S. Praveen Kumar, S. Munusamy, S. Muthamizh, A. Stephen, V. Narayanan, Sens. Actuators $B, \mathbf{2 0 1 4}, 202,440-447$.

[27] H. Heli, H. Yadegari, Electrochim. Acta, 2010, 55, 2139-2148.

[28] J. P. Lei, H. Huang, X. L. Dong, L. P. Sun, B. Lu, M. K. Lei, Q. Wang, C. Dong, G. Z. Cao, Int. J. Hydrogen Energy, 2009, 34, 8127-8134.

[29] P. V. Samant, J. B. Fernandes, J. Power Sources, 1999, 79, 114-118.

[30] B. Liu, J. H. Chen, C. H. Xiao, K. Z. Cui, L. Yang, H. L. Pang, Y. F. Kuang, Energy Fuels, 2007, 21, 1365-1369.

[31] S. A. Fadl-Allah, R. M. El-Sherief, W. A. Badawy, J. Appl. Electrochem., 2008, 38, 1459-1466.

[32] H. K. Lee, H. Y. Lee, J. M. Jeon, Surf. Coat. Technol., 2007, 201, 4711-4717.

[33] M. A. M. Ibrahim, J. Appl. Electrochem., 2006, 36, 295-301.

[34] N. Guglielmi, J. Electrochem. Soc., 1972, 119, 1009-1012.

[35] S. Shawki, Z. Abdel Hamid, Anti-Corros. Method Mater., 1997, 44, 178-185.

[36] R. Q. Fratari, A. Robin, Surf. Coat. Technol., 2006, 200, 4082-4090.

[37] R. Winand, Hydrometallurgy, 1992, 29, 567-598.

[38] R. Winand, Electrochim. Acta, 1994, 39, 1091-1105.

[39] R. Winand, J. Appl. Electrochem., 1991, 21, 377-385.

[40] W. Schmickler, Interfacial Electrochemistry, Oxford University Press, Oxford, 1996.

[41] B. D. Cullity, Elements of X-Ray Diffraction, 2nd ed., Addison Wesley Publishing, London, 1978.

[42] P. M. Robertson, J. Electroanal. Chem. Interfacial Electrochem., 1980, 111, 97-104.

[43] M. Fleischmann, K. Korinek, D. Pletcher, J. Electroanal. Chem., 1971, 31, 39-49.

[44] P. Oliva, J. Leonardi, J. F. Laurent, C. Delmas, J. J. Braconnier, M.
Figlarz, F. Fievet, A. de Guibert, J. Power Sources, 1982, 8, 229-255.

[45] L. Garcia-Cruz, A. Saez, C. O. Ania, J. Solla-Gullon, T. Thiemann, J. Iniesta, V. Montiel, Carbon, 2014, 73, 291-302.

[46] M. Pourbaix, Atlas of Electrochemical Equilibria in Aqueous Solutions, National Association of Corrosion Engineers, Houston, Texas, USA, 1974.

[47] R. Barnard, C. F. Randell, F. L. Tye, J. Appl. Electrochem., 1980, 10, 109-125.

[48] R. S. Schrebler-Guzman, J. R. Vilche, A. J. Arvia, J. Appl. Electrochem., 1978, 8, 67-70.

[49] J. Wang, Analytical Electrochemistry, 3rd ed., John Wiley \& Sons Inc., New Jersey, 2006.

[50] A. Döner, E. Telli, G. Kardas, J. Power Sources, 2012, 205, 71-79.

[51] A. M. Fekry, Electrochim. Acta, 2009, 54, 3480-3489.

[52] A. Maritan, F. Toigo, Electrochim. Acta, 1990, 35, 141-145.

[53] Y. C. Liu, X. P. Qiu, W. T. Zhu, G. S. Wu, J. Power Sources, 2003, 114, $10-14$.

[54] J. T. Mueller, P. M. Urban, J. Power Sources, 1998, 75, 139-143.

[55] Y. Bultel, L. Genies, O. Antoine, P. Ozil, R. Durand, J. Electroanal. Chem., 2002, 527, 143-155.

[56] E. Hao Yu, K. Scott, R. W. Reeve, J. Electroanal. Chem., 2003, 547, $17-24$.

[57] G. J. Brug, A. L. G. Van Den Eeden, M. Sluyters-Rehbach, J. H. Sluyters, J. Electroanal. Chem. Interfacial Electrochem., 1984, 176, 275-295.

[58] R. K. Shervedani, A. Lasia, J. Appl. Electrochem., 1999, 29, 979-986.

[59] M. Fleischmann, K. Korinek, D. Pletcher, J. Chem. Soc. Perkin Trans. 2, 1972, 1396-1403.

[60] P. M. Robertson, J. Electroanal. Chem. Interfacial Electrochem., 1980, 111, 97-104.

[61] J. Taraszewska, G. Roslonek, J. Electroanal. Chem., 1994, 364, 209-213.

[62] A. A. El-Shafei, J. Electroanal. Chem., 1999, 471, 89-95.

[63] I. Danaee, M. Jafarian, A. Mirzapoor, F. Gobal, M. G. Mahjani, Electrochim. Acta, 2010, 55, 2093-2100.

\title{
碳电极上电沉积的 $\mathrm{Ni}-\mathrm{MgO}$ 纳米复合物催化甲醇和乙醇电氧化反应
}

\author{
H. B. Hassana ${ }^{\text {a, }}$, Z. Abdel Hamid ${ }^{\text {b,\#, Rabab M. El-Sherif a }}$ \\ a开罗大学理学院化学系, 吉萨, 埃及

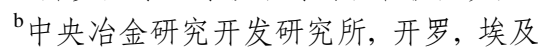

摘要: 在细小 $\mathrm{MgO}$ 增强颗粒的存在下, 采用电沉积法在碳阳极上经瓦特镍制得 $\mathrm{Ni}-\mathrm{MgO}$ 纳米复合物, 考察了它在碱性介质 中电催化氧化甲醇和乙醇反应性能, 并与碳涂覆的纯 $\mathrm{Ni}$ 催化剂(Ni/C)性能进行了比较. 运用能量散射谱、X射线衍射和扫描 电镜分别表征了沉积的纳米复合物的化学组成、相结构和表面形貌, 并采用循环伏安法 $(\mathrm{CV})$ 、计时电流法和电化学阻抗谱 (EIS)等电化学技术考察了所制电催化剂阳极的催化活性. 结果表明, Ni/C催化剂在电氧化反应中表现出很低的催化活性 和稳定性, 而 $\mathrm{MgO}$ 的引入显著增加了 $\mathrm{Ni}$ 催化剂在醇氧化反应中的催化活性和抗中毒性能. EIS 和CV结果证实 $\mathrm{Ni}-\mathrm{MgO} / \mathrm{C}$ 纳 米复合物电极具有比 Ni/C更低的电荷转移阻力和更高的抗中毒性能.

关键词: 镍修饰; 氧化镁; 电氧化; 甲醇; 乙醇; 电化学阻抗谱; 循环伏安法

收稿日期: 2015-10-06. 接受日期: 2015-12-22. 出版日期: 2016-04-05.

*通讯联系人. 电话: +20-1003871963; 电子信箱: hanaa20055@hotmail.com

\#通讯联系人. 电子信箱: zamiabdelhamid@hotmail.com

本文的英文电子版由Elsevier出版社在ScienceDirect上出版(http://www.sciencedirect.com/science/journal/18722067). 